\title{
Geographic clustering of longevity in a Dutch province, 1812-1962 \\ How stable, behavior-associated environmental characteristics explain the local clustering of longevity
}

Rick Mourits, Radboud University Nijmegen, the Netherlands. Email: r.mourits@let.ru.nl Angelique Janssens, Radboud University Nijmegen, the Netherlands. Email: a.janssens@let.ru.nl

The authors would like to thank Hannaliis Jaadla, Sebastian Klüsener, Jan Kok and Theo Engelen for their methodological and theoretical feedback. Furthermore, we thank the Humanities Lab, Faculty of Arts, Radboud University for providing the map with Zeeland islands and municipalities.

\begin{abstract}
There are places that bring forth unexpectedly large numbers of long-lived individuals. In this study, we explore which factors affect geographic clustering of longevity and indicate whether survival advantages occur early in life, later in life, or over the entire lifespan. 150 years of mortality data are used to reconstruct the lifespans of the 1812-1862 Zeeland cohort, resulting in a sample of 176,577 individuals from 101 municipalities. We found evidence of longevity clustering for women. Geographic patterns in longevity were similar for men, but not statistically significant. For both sexes, the environment affects individuals over the entire life course and not in early or later life only. Inhabitants of neighboring municipalities resemble each other in their chances to become long-lived, because their hometowns had similar agricultural practices, demographic pressure, and levels of poverty, whereas the religious denomination or population density of a municipality had no effect on individual chances to become long-lived. Our findings underline the importance of the living environment for individual chances to become long-lived. Moreover, it shows that geographic clustering of longevity in Zeeland were explained by an interaction between human behavior and the environment that affected individual survival chances over the entire lifespan.
\end{abstract}




\section{Introduction}

Multiple studies have shown that there are places that bring forth unexpectedly large numbers of long-lived individuals. Geographic clustering of longevity occurs at a global (Poulain, Herm \& Pes, 2013; Rosero-Bixby, Dow \& Rehkopf, 2013), national (Gavrilov \& Gavrilova, 2015; Montesanto et al., 2017), and regional level (Caselli \& Lipsi, 2006; Pes et al., 2013; Roli et al., 2012). However, much ground has yet to be covered in understanding how the living environment can affect an individual's chances to become long-lived. Geographic studies on the contemporary clustering of longevity have linked geographic features to healthy lifestyles. At a global level, the abstinence from alcohol and smoking, geographic isolation, and healthy diets are used to explain longevity clusters (LindahlJacobsen et al., 2013; Pes et al., 2013; Temby \& Smith, 2014). However, whether and how geographic features themselves affect longevity and clustering is less well understood. Isolated, mountainous regions have been associated with increased individual chances to become long-lived, but insights into reasons for regional longevity clustering do not reach much further (Pes et al., 2013; Roli et al., 2012). We argue that historical demographic research can give further insight into the mechanisms behind geographic clustering of longevity as well as environmental influences on longevity in general.

The historical literature on the association between the environment and mortality has focused on three factors: religion, soil type, and urbanization (Devos \& Van Rossem, 2017; van den Boomen \& Rotering, 2018; Wolleswinkel-van den Bosch et al., 2001). Religion is used as a proxy for more temperate lifestyles, causing abstinence of alcohol and tobacco, and networks of care and social support (Koenig, King \& Carson, 2012; Kok, 2017). Soil type has been associated with access to clean drinking water and disease environments, which increase exposure to infectious diseases. Moreover, farm sizes and agricultural practices differed considerably by soil type, affecting access to food and local diets (Devos \& Van Rossem, 2017; Hedefalk, Quaranta \& Bengtsson, 2017; Hofstee, 1981; van den Boomen \& Ekamper, 2015; van den Boomen \& Rotering, 2018; Wolleswinkel-van den Bosch et al., 2001). Finally, urbanization is thought to increase mortality, as possible beneficial effects of available services were negated by the negative effects of overcrowding, cottage industry, and slumming (see e.g. Eggerickx \& Debuisson, 1990; Kesztenbaum \& Rosenthal, 2011; Reher, 2001; Van der Woud, 2010; Van Rossem, Deboosere \& Devos, 2017; Vögele, 1998). However, in less overcrowded regions, living in an urban environment could also be beneficial for survival in later life (Gagnon et al., 2009; Temby \& Smith, 2014). Hence, the historical literature has established multiple pathways through which the environment can affect human survival. Yet, whether these pathways also affect individual chances to become long-lived has yet to be explored.

The historical frameworks that link the environment to human mortality are tested from a life course perspective. Currently, we know that longevity clusters geographically, but not at which ages these environments are associated with significant survival advantages. When many people lived to advanced ages, it shows that certain environments benefit human survival. However, this could have happened early in life, later in life, or consistently over the life course. Therefore, not only our insight into geographic determinants of longevity is limited, so is our understanding of when these factors benefit human survival. One needs to wonder when the environment affects survival, as environmental effects might differ by age. Sardinia is, for example, known for its high share of centenarians (Poulain, Herm, \& Pes, 2013), but is not known for its low mortality rates between ages 85 and 94 in comparison to other regions in Europe (Ribeiro et al., 2016). Studying whether longevity clustering increases or decreases over the life course helps to pinpoint which causes of mortality are 
suppressed, which in turn can give important insight into the mechanisms underlying geographic clustering of longevity.

In this paper, we use 150 years of mortality data to study geographic clustering of longevity for 101 municipalities in the Dutch province of Zeeland. We explain how theoretical frameworks based on interregional differences in child mortality can also be applied to longevity clustering in this island region. Data on 176,577 individuals from 101 municipalities in Zeeland is used to answer whether and why longevity clustered geographically in Zeeland. First, geographic clustering in the proportion of long-lived individuals per municipality is estimated. Second, we test whether the spatial clustering changes when we model longevity clustering for women and men separately. Third, we test whether the clustering degree of longevity is stable over the entire life course. Fourth, we test for environmental factors to see if these geographic features explain the spatial clustering. Last, we use these outcomes to reflect on the existing theoretical framework. This will help us answer four questions: (1) Did longevity cluster in certain municipalities in Zeeland? (2) Is the clustering of longevity in Zeeland sex-specific? (3) Is the spatial clustering of longevity stable over time? and (4) Which environmental factors affected longevity?

\section{The Zeeland context}

In this paragraph we discuss how the geographic features of Zeeland might have affected individual chances to become long-lived. Zeeland is an island archipelago in the southwest of the Netherlands, bordering Belgium and the North Sea. The region is interesting for a case study on the relationship between the living environment and longevity for multiple reasons. First, the province was religiously mixed, housing Roman Catholic, liberal Protestant, and orthodox Protestant religious communities (Knippenberg, 1992). This allows us to disentangle religious composition and geographic features. Second, the province was a coastal region with one dominant soil type: clay (WUR-Alterra, 2006). Health risks associated with access to clean drinking water were similar for the entire province. Yet, there were important difference between municipalities on sandy clay soils and on clay soils in terms of waterlogging and agricultural practices. This makes it possible to focus more deeply on the effects underlying the mortality differences between soil and sand regions. Third, Zeeland is a largely rural province (Bras, 2002; Priester, 1998; Van Leeuwen \& Maas, 2007) which did not strongly urbanize during the $19^{\text {th }}$ century. Therefore, differences in survival between cities and rural towns are less likely to be caused by overcrowding. Most importantly, however, Zeeland is not known as a healthy environment. During the $19^{\text {th }}$ century Zeeland had little population growth due to high mortality ${ }^{1}$ and outmigration (Hofstee, 1981; Nederlandsche Maatschappij tot Bevordering der Geneeskunst, 1879; Van den Berg, Van Dijk, Mourits, et al., 2018). As a whole, these four characteristics make Zeeland an interesting case to explore how religion, soil, and city size affected individual chances to become long-lived.

\footnotetext{
1 The high mortality was mainly caused by high infant mortality (Hoogerhuis, 2003; Van Dijk \& Mandemakers, 2018). Relatively high mortality rates also existed between ages 18 and 85 (Van Dijk, Janssens \& Smith, 2018), but seems to be at least partly caused by selective outmigration (Van den Berg, Van Dijk, Mourits, et al., 2018). When we look at survival at age 50, when migration reaches a low (Kok, 1997), the average age at death in Zeeland is highly comparable to the average age at death in Utah, which is known for its long-lived population. However, top survivors in Utah lived much longer than top survivors in Zeeland (Mourits, Smith \& Janssens, 2018).
} 


\subsection{Religion}

Since the Reformation, the Netherlands has been a religiously divided country (Knippenberg, 1992). As a general rule of thumb, it can be said that the north of the country was Protestant, whereas the southeast was Roman-Catholic. Roman-Catholicism was the dominant religion in Brabant, Limburg, and the southern parts of Gelderland, whereas in the other provinces most individuals were Protestant. The geographic divide between a Protestant north and a Roman-Catholic south makes it seem like there were two homogenous religious regions in the Netherlands. However, the 'north' was not a religiously homogenous zone. First, religious communities often collided with local borders, creating denominational and theological differences between places. Roman-Catholic religious communities can be found along the Holland coastline, in the east of the country, the south of Zeeland and - to a lesser degree - in rural South Holland and western Utrecht (Knippenberg, 1992). Second, Protestantism refers to a widely diverging group of Churches among which the Dutch Reformed Church was by far the largest. The dominant Dutch Reformed Church was an amalgam of different religious communities, "ranging from ultra-liberal to ultra-orthodox" (Kok, 2017, p. 60). As such, most provinces were a patchwork of liberal-Protestant, orthodox-Protestant and RomanCatholic religious communities.

Zeeland also consisted of Roman-Catholic, liberal Protestant, and orthodox Protestant communities. In total, approximately half of the population was liberal Protestant, whereas one quarter was Roman-Catholic and another quarter orthodox Protestant (see table A1). Religion had a significant impact on daily life, as the church instilled values and norms regarding family, sexuality, and marriage (Kok, 2017). A wide range of literature has shown that religion is also associated with mortality in later life. In general, religion is thought to decrease mortality rates by promoting temperance of alcohol, tobacco, and diets, helping followers cope with adversity, and stimulating social support (Koenig, King \& Carson, 2012). Increased levels of survival have been found among followers of religious communities with high levels of social control and strong regulations on the abstinence from alcohol and tobacco, e.g. Mormons, Seventh-Day-Adventists, and Old Order Amish (Fraser, 1999; Hamman, Barancik \& Lilienfeld, 1981; Lindahl-Jacobsen et al., 2013; Temby \& Smith, 2014). These groups seem to show an extreme example of a general principle: increased religious participation is associated with decreased alcohol intake, less tobacco consumption, and a lower chance on a poor diet (Koenig et al., 2012). These mechanisms are not only present in contemporary society. Around the turn of the $20^{\text {th }}$ century when, Liberal Protestants in the Netherlands - which were members of a highly secularized church - had higher levels of old-age mortality than Orthodox Protestants, Roman-Catholics, or Jewish families (Kok, 2017). Furthermore, inactive Mormons in Utah had higher mortality levels than active Mormons and a lower chance to become long-lived (LindahlJacobsen et al., 2013; Temby \& Smith, 2014). Hence, increased involvement in a religious community has been associated with increased survival rates.

\subsection{Soil}

Besides religion, regional differences have also been explained by differences between coastal and inland regions (Devos \& Van Rossem, 2017; Hofstee, 1981; van den Boomen \& Rotering, 2018; Wolleswinkel-van den Bosch et al., 2001). The difference between coastal and inland areas is often summarized as a difference between sand and clay. In the inland municipalities where the main soil type is sand, individuals had lower mortality rates than residents of municipalities dominated by clay. Differences in survival by soil type have been explained by the disease climate, access to clean 
drinking water, and agricultural traditions (Devos \& Van Rossem, 2017; Hofstee, 1981). The first two explanations hypothesize that differences between porous sandy soils and waterlogged clay soils are in fact a juxtaposition between drylands and wetlands (Hedefalk, Quaranta \& Bengtsson, 2017; Munro et al., 1997). The wetlands were an excellent breeding ground for pathogens. Waterlogging created pools and puddles which were fertile breeding ground for mosquitoes that transmitted malaria. Clean drinking water was also less readily available on the coast than in inland regions. People were dependent on collecting rainwater, as groundwater was often salinized or contaminated by feces and waste from nearby cesspools and canals. Hence, drinking surface water or using it for cleaning purposes was not without risk (Hofstee, 1983; van den Boomen \& Ekamper, 2015). A third explanation focuses on the relation between soil type and intensive agriculture (Devos \& Van Rossem, 2017). Sandy soils were relatively unfertile and required intensive labor. As a result, inland farming was not restricted by the availability of land, but the amount of land a farmer could work, whereas in coastal regions farms were larger and relied on hired labor. Hence, the living environment determined whether individuals produced their own food or were hired laborers.

In Zeeland, differences in access to clean drinking water were practically non-existent, as everywhere groundwater was salinized due the vicinity to the sea. To keep livestock hydrated, farmers dug basins to collect rainwater (Priester, 1998) and inhabitants collected their own drinking water from roofs in rainwater tanks. Some households had their own tanks, but it was not uncommon that households in the city shared these water tanks (Hoogerhuis, 2003). Moreover, except for its dune regions, Zeeland had no sandy soils (WUR-Alterra, 2006). Nevertheless, significant differences existed in the use of clay and sandy clay soils (Priester, 1998). The difference between clay and sandy clay corresponds with different polders in Zeeland known as oudland [old land] and nieuwland [new land]. These terms - old and new land - refer to the origin of different regions. Oudland was the first embanked land in the Zeeland delta, which was reclaimed between 1000 and 1200. It is the lowest lying land in Zeeland and consists of clay resting on layers of peat. Due to high soil acidity and salinity, possibilities for agriculture were limited as even crops resistant to saline and acid soils - beets, potatoes, grain, and madder - were hard to grow on these fields. Nieuwland, where the soil consists of a mixture of sand and clay, was much more fertile and often used for agriculture (Priester, 1998). For our study it is important to know that oudland was more likely to waterlog, generally used as grassland rather than farmland, and had smaller farms.

Pools and puddles of brackish water were an excellent breeding ground for malaria mosquitoes. So much so, that Zeeland was notorious for its intermittent fevers (Van der Kaaden, 2003). Especially people new to the region and young children were at risk (Van der Kaaden, 2003; van Poppel, Ekamper \& Mandemakers, 2018). Because rainwater could not easily seep away from the oudland polders, one would expect a higher incidence of malaria in these regions of Zeeland. However, life was not all bad in the oudland. Although livestock farming in Zeeland was rare, grassland was more common in the oudland regions (Priester, 1998). Farmer's wives were often involved in cheesemaking to contribute to the household income. In general, this meant that households were somewhat wealthier (Van Cruyningen, 2005). It also might have helped that farms in the oudland were smaller (Priester, 1998) and required fewer farm laborers. The lower dependency on farm laborers meant that more households produced their own food and were not dependent on their employer or the market to acquire food. In general, farming seems to have been beneficial for men, as farmers and - to a lesser degree - farm laborers lived longer than other men (Edvinsson \& Broström, 2012; Ferrie, 2003; Mourits, Smith \& Janssens, 2018; Schenk \& van Poppel, 2011; Smith et 
al., 2009). For women, such an effect has never been found (Alter, Dribe \& Van Poppel, 2007; Edvinsson \& Broström, 2012; Schenk \& van Poppel, 2011; Zimmer, Hanson \& Smith, 2016). Following this line of reasoning, individuals who produced their own food might have had a better chance to become long-lived. Hence, inhabitants of municipalities with smaller farms could have lived longer than individuals from towns with large-scale farms that focused on market production.

\subsection{Urbanization}

Besides religion and factors associated with soil use, we control for several characteristics of urbanization in the Zeeland context. For Zeeland, the $19^{\text {th }}$ century was a period of economic decline. Before the $19^{\text {th }}$ century, Zeeland had been a relatively wealthy province. Between 1600 and 1800 , Zeeland was home to the West-Indische Compagnie and had a positive net migration rate to attract laborers for the expanding economy (Priester, 1998). However, during the $19^{\text {th }}$ and early $20^{\text {th }}$ century, the province was characterized by outmigration and many people left for Rotterdam or the new world. Steady outmigration probably was a way to cope with the economic stagnation that occurred in Zeeland. The tendency to leave the province can be attributed to an excess of labor force in the province (Priester, 1998). This phenomenon also occurred in other saturated habitats that had little room for spatial or demographic expansion (see e.g. Voland \& Dunbar, 1995). Besides relieving demographic pressure from the less attractive municipalities in Zeeland, the outmigration also prevented urbanization. Whereas elsewhere in the Netherlands cities grew like never before, resulting in overcrowding and slums (Van der Woud, 2010), the population of Zeeland and its urban centres grew only modestly (see Figure A1). Therefore, urban centres were not as plagued by overcrowding as the rising metropoles. In many of the larger towns, people had their own rain tanks or shared it with a limited number of people (Hoogerhuis, 2003).

Nevertheless, there were multiple towns with a regional function in Zeeland. Each island had one or multiple larger towns that functioned as the center of trade for the other rural towns (Bras, 2002). These towns served as gateways to the islands and had small docks where regular passenger and cargo shipments arrived and left. Oftentimes, these ships sailed to Middelburg and Rotterdam at least once per week (De Kanter \& Utrecht-Dresselhuys, 1824), so that the islands were never really secluded from the outside world. There were also connections to Brabant, Antwerpen, Gent, Brugge and major cities in Holland, but to reach these places one generally had to travel over Middelburg, Goes, Zierikzee, or Terneuzen. The island structure with larger towns functioning as gateways to the island, meant that each island had a town that catered to the basic needs of the inhabitants of the other rural settlements on the island. Therefore, most individuals never had to leave the island (Bras, 2002), unless they left to find work elsewhere. 
Figure 1: Islands and municipalities in Zeeland

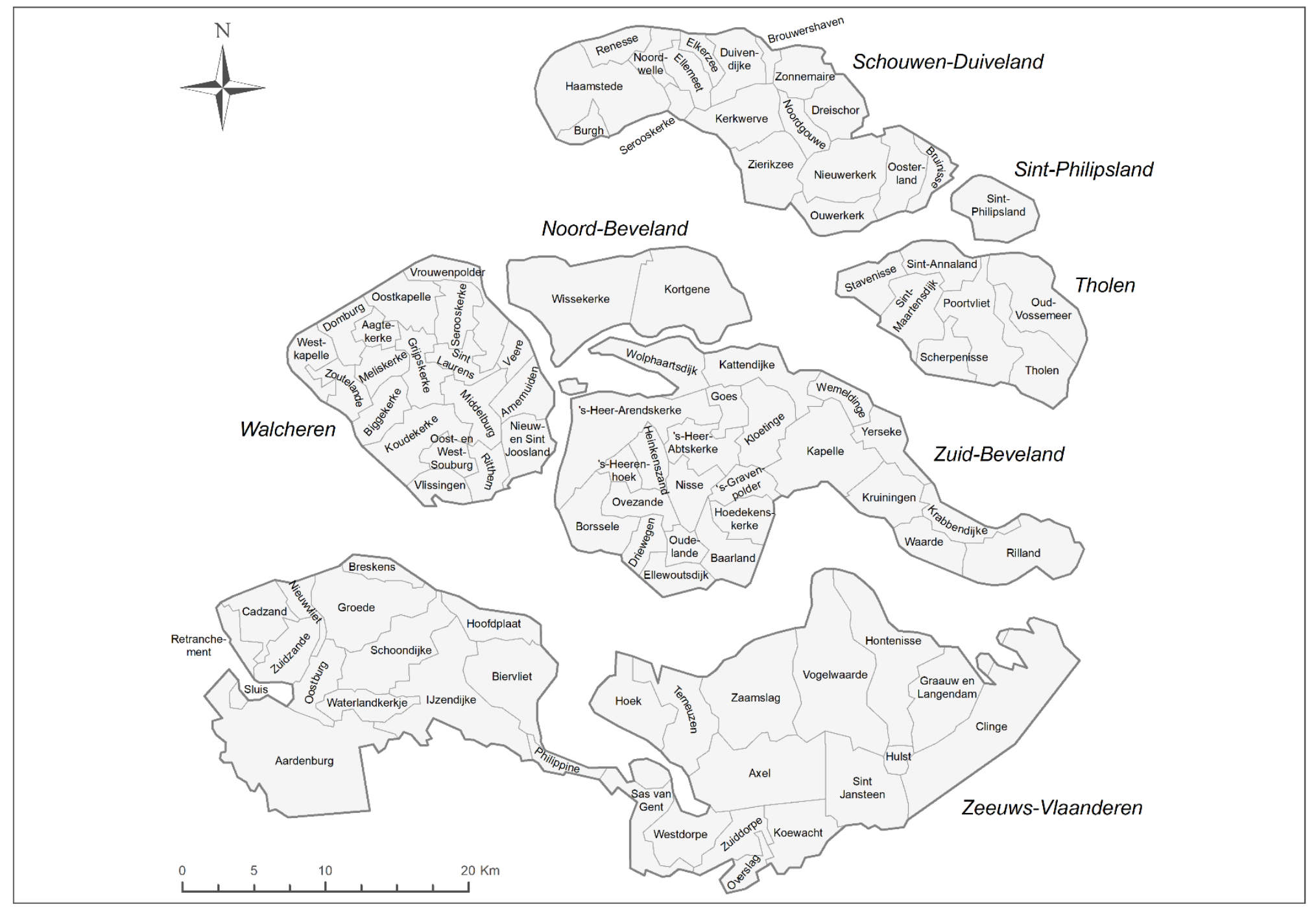

(Hermsen, 2018) 


\section{Data \& variables}

To study the effect of the living environment on individual survival, we use data from LINKS-Zeeland (Mandemakers \& Laan, 2017). The LINKS-dataset contains family and life course reconstructions based on the Zeeland civil registry. Birth, marriage, and death certificates are available between 1812 and 1912/1937/1962, respectively. These certificates are matched based on indexed names of ego, father, mother, and spouses. To ascertain the quality of our sample, we selected individuals who were born in Zeeland between 1812 and 1862 and had known family members (Van den Berg, Van Dijk, Mourits, et al., 2018). This resulted in a sample of 232,838 individuals from 48,844 different families. Due to outmigration and a limited number of failed linkages, no age at death was known for 56,261 individuals. We dropped these individuals, as they moved of the Zeeland context and no information on their age at death was known. Hence, the resulting sample of 176,577 individuals consists of individuals who lived and died in Zeeland. Table A6 shows the number of observations per municipality.

Longevity was measured dichotomously. To be considered long-lived, men and women had to belong to the oldest $10 \%$ from their sex-specific birth cohort as defined in earlier research (Van den Berg, et al., 2018). Thresholds for belonging to the top survivors are derived from Swedish cohort life tables, since these are the only existing cohort life tables for the early $19^{\text {th }}$ century (Human Mortality Database, 2018). This procedure prevents selection biases due to out-migration and, thus, false inquiries into the nature of longevity. In our sample, the average share of long-lived people per municipality is $5.8 \%$ with a standard deviation of $1.3 \%$. In total $5.3 \%$ of all women and $6.4 \%$ of all men could be considered long-lived, with standard deviations of $1.4 \%$ and $1.7 \%$ respectively. These estimations are below $10 \%$, due to high infant mortality in comparison to Sweden and outmigration in Zeeland.

Religion was retrieved from the 1869 census, which distinguishes between 17 different religious denominations. For each municipality we selected the religious denomination that was practiced by at least two third of the population. The Dutch Reformed municipalities were split up based on their religious orientation towards liberalism or orthodoxy, as available for 1920. Members of the Dutch Reformed Church elected their own church council, which in turn called a minister to a parish. Hence, whether Dutch Reformed ministers in a municipality preached Liberal or Orthodox theology is a good indication of how fundamentalist the Dutch Reformed religious communities were (Kok, 2017). Municipalities that had only Vrijzinnig Hervormden [Liberal] or Ethisch Hervormden [Ethical] ministers were coded as liberal, whereas municipalities with solely Confessioneel Hervormden [Confessional] or Gereformeerd Hervormden [Reformed] ministers were considered orthodox. Municipalities with both orthodox and liberal ministers were coded as mixed. This procedure showed that there were 52 Liberal Protestant, 19 Orthodox Protestant, and 17 Roman Catholic municipalities. In 13 municipalities, there was no religious majority. Supplementary Figure A2 shows the different religious denominations per municipality.

Soil type was reconstructed using a soil map provided by the Alterra institute at the Wageningen University (WUR-Alterra, 2006). The soil map shows at a scale of $1: 50,000$ whether the soil is composed of: peat, sand, sandy clay (light or heavy), clay (light or heavy), or loam. For each municipality we determined the dominant soil type by overlaying the soil map with the municipal map of Zeeland. As Zeeland is a river delta, clay and sandy clay are the most common soil types. For our analyses we distinguish between these two soils types as they refer to oudland and nieuwland. Therefore, we make no distinction between light and heavy clay or light and heavy sandy clay. There 
were three municipalities were sand was the dominant soil type. ${ }^{2}$ These municipalities have been added to the reference category. Hence, we identified 75 municipalities with sandy clay and 26 municipalities with clay as their dominant soil type. Supplementary Figure A3 shows the soil type per municipality.

The labor force working in agriculture is retrieved from the 1930 census as available in the Historical Databank Nederlandse Gemeenten (Beekink et al., 2003), because municipal level data on the work force was not available in the occupational censuses of 1889 and 1899. Domestic work was often not included in the census. Therefore, we only included the male share of the labor force working in agriculture. Supplementary Figure A7 shows the share of the labor force working in agriculture per municipality. In the rural municipalities, occupations other than farming were relatively rare. As such, the more men worked as a farmers, the fewer men worked in any of the other major economic sectors in Zeeland (see supplementary Table A3). We further include the average net taxable income per person as available in the 1875 Verslag van den Landbouw (Ministerie van Binnenlandse Zaken, 1875). This document was compiled by the Ministry of the Interior and contains information on the number of inhabitants from the 1869 census and net taxable income as mentioned by the Bescheiden betreffende de geldmiddelen published by the Treasury (Departement van Financiën, 1869). The net taxable income per person refers to the estimated profit from agricultural land and buildings, controlled for the number of inhabitants. This measure gives insight in rural inequalities in income. As shown in supplementary Figure A6, the net taxable income per capita was lowest in cities. On the countryside, however, differences in net taxable income per person varied significantly. There were considerable differences between the municipalities in the size of farms and, as a result, the ratio between agricultural laborers and farmers. A high per capita net taxable income shows that farms were larger, worked by more agricultural laborers, and focused on cash crops. Therefore, a high per capita net taxable income can be seen as an indicator of inequality and a preference for marketoriented agriculture.

The number of inhabitants and population density are also retrieved from the 1875 Verslag van den Landbouw (Ministerie van Binnenlandse Zaken, 1875). Besides the number of inhabitants and net taxable income, the 1875 Verslag van den Landbouw also contains information on the size of the municipality in hectares and population density. Population density was available as a continuous variable, but had to be recoded before it could be entered into our analyses as the variable is not normally distributed. Most municipalities in Zeeland have on average a population density of around 900 inhabitants per square hectare, ranging between 183 and 2,316 inhabitants per square hectare. However, seven municipalities - Goes, Hulst, Middelburg, Sluis, Veere, Vlissingen, and Zierikzee - had between 4,000 and 12,000 inhabitants per square hectare. Therefore, we recoded the variables into three categories: $<1,000$ inhabitants per square hectare, 1,000-2,500 inhabitants per square hectare, and $>4,000$ inhabitants per square hectare. Supplementary Figures A4 and A5 show the number of inhabitants and populations density per municipality.

Besides degrees of urbanization, we also indicate whether towns had a regional function for other rural settlements. Each island had its own regional center where people traded and ferries sailed to other ports in Zeeland. These towns were too small for slumming to occur, but activities such as trade were more prominent in these towns than one would expect from a rural town. To control for these unique characteristics of island centers, we measured the share of traders in a municipality.

\footnotetext{
${ }^{2}$ Renesse and Haamstede near the dunes and Overslag in the most southern part of Zeeland.
} 
Just like the labor force working in agriculture, the share of traders in a municipality is retrieved from the 1930 census as available in the Historical Databank Nederlandse Gemeenten (Beekink et al., 2003). Again, we base ourselves on the male population. Except for agriculture, the share of labor force working in trade was not correlated with the share of the labor force in any of the other economic sectors in Zeeland (see supplementary Table A3). Supplementary Figure A8 shows the share of the labor force working in trade per municipality. Last, we include the net migration rate as an indicator of demographic pressure and saturation of the labor market. The net migration rate is retrieved from the Gemeentelijk Demografische Documentatie of the Central Bureau for Statistics as available in the Historical Databank Nederlandse Gemeenten (Beekink et al., 2003). The migration rate is measured as: the average number of immigrants in a municipality between 1851 and 1880 minus the average number of emigrants in a municipality between 1851 and 1880, divided by the size of the municipality. Supplementary Figure A9 shows the net migration rate per municipality.

Table 1: correlation matrix of continuous variables

\begin{tabular}{|l|c|c|c|c|c|}
\hline & $\begin{array}{c}\text { Number of } \\
\text { inhabitants }\end{array}$ & $\begin{array}{c}\text { Net taxable } \\
\text { income p.c. }\end{array}$ & $\begin{array}{c}\text { Share of } \\
\text { labor force in } \\
\text { agriculture }\end{array}$ & $\begin{array}{c}\text { Share of } \\
\text { labor force in } \\
\text { trade }\end{array}$ & $\begin{array}{c}\text { Migration } \\
\text { rate }\end{array}$ \\
\hline Number of inhabitants & 1 & & & & \\
\hline Net taxable income p.c. & -.22 & 1 & & & \\
\hline $\begin{array}{l}\text { Share of labor force } \\
\text { working in agriculture }\end{array}$ & -.54 & .22 & 1 & & \\
\hline $\begin{array}{l}\text { Share of labor force } \\
\text { working in trade }\end{array}$ & .60 & -.12 & -.70 & 1 & .13 \\
\hline Net migration rate & .14 & -.54 & -.19 & & 1 \\
\hline
\end{tabular}

\subsection{Neighbourhood matrix}

For our analyses, we use shapefiles provided by Boonstra (Boonstra, 2007). Municipal borders in Zeeland changed considerably during our period of observation. Between 1812 and 1862 the number of municipalities decreased from 144 to 113 municipalities. During the period of observation, the number of municipalities decreased even further until 86 municipalities in 1962 (Van der Meer \& Boonstra, 2006). To be able to compare our birth cohorts, we selected the shapefiles containing the municipal borders of 1860 to map differences between Zeeland municipalities and compute neighbourhood matrices. Due to restrictions in our data, we merged Eede and Sint Kruis with Aardenburg, Kats with Kortgene, Schore met Kapelle, Bath and Rilland into Rilland-Bath, Sint Anna ter Muiden and Heille with Sluis, and Boschkapelle, Hengstijk, Ossenisse, and Stoppeldijk into Vogelwaarde. The resulting map for Zeeland is shown in Figure 1.

We tested which neighbourhood matrix was most accurate to calculate the Moran's I statistic of spatial autocorrelation. Neighbourhood matrices define which municipalities border one another and are required to compute clustering of longevity. Because Zeeland is an island region, water could form a natural border between nearby municipalities. Therefore, neighbourhood matrices can only be constructed for municipalities that neighbour one another. This can be done in two ways, depending on whether one defines neighbours by geographic divides or human traveling routes. The first approach sees water as a natural border and sees municipalities that directly border one another as neighbours. The second perspective not only identifies municipalities with a land 
connection as neighbours, but also those that are connected by ferry. To be able to determine whether longevity clustering associated more strongly with environmental features or human travelling routes, we constructed two neighbourhood matrices.

The neighbourhood matrix that controlled for land connections contained all adjacent municipalities which were retrieved using the queens method. The graphical representation of the corresponding neighbourhood matrix is shown in Figure 2A. The second neighbourhood matrix contained both land and ferry connections that sailed regularly between the islands. We added the ferry lines as operating in 1824 (De Kanter \& Utrecht-Dresselhuys, 1824) to the neighbourhood matrix retrieved using the queens method. The graphical representation of the matrix is shown in Figure 2B. The ferry lines are shown as red, dotted lines. It turned out that spatial autocorrelation was higher when we used the neighbourhood matrix without ferry connections. Neighbouring municipalities were more similar if we only took geographic adjacency into account and not human travel routes. Hence, we used the queens method to further study the geographic clustering of longevity in Zeeland.

Figure 2: Neighbouring municipalities (black) + ferry connections (red) in Zeeland
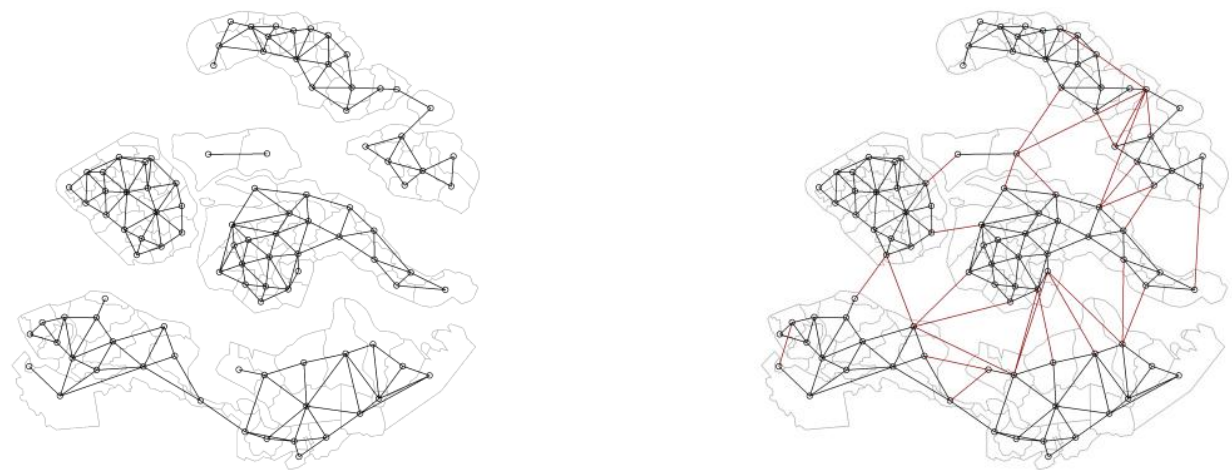

\subsection{Method}

To measure geographic clustering of longevity, we ran empty multi-level models with belonging to the top $10 \%$ as the dependent variable. From the residuals we calculated the Moran's I, which measures spatial autocorrelation. This procedure checked whether the chance to become long-lived was similar for neighboring municipalities or randomly distributed over the province. To determine whether the spatial clustering of longevity was stable over the life course, we repeated the regression analyses four times. Each time, we used a different starting age $-5,20,30$, and 50 instead of 0 - to see whether spatial clustering of longevity in the null models' residuals increased, decreased, or remained stable if we moved the observation window. An increasing Moran's I means that spatial clustering is stronger at older ages, whereas a decreasing Moran's I hints at the importance of the environment in early life. A stable Moran's I, on the other hand, indicates that environment features have a stable effect over the life course on an individual's chances to become long-lived.

If longevity clustered geographically, we violated an assumption of the multi-level regression model and cannot interpret the models until we can explain the spatial clustering. Therefore, we added 
environmental variables (dominant religion, soil type, population density, population size, net taxable income per capita, economic focus, and the migration rate) to see if these variables explain spatial clustering. The main goal of these models is to see whether the Moran's I decreases and becomes insignificant. In such cases, we conclude that certain geographic indicators explain geographic clustering of longevity. This does not necessarily mean that the geographic features themselves explain clustering, but rather that they are a proxy for an underlying mechanism (e.g. soil type is a proxy for waterlogging, agricultural traditions, etc.).

\section{Results}

In this paragraph, we test whether individuals born in neighboring municipalities, had similar chances to belong to the top $10 \%$ longest-lived individuals. Chances to become long-lived are estimated using multilevel regression models. We report the Moran's I index of clustering to test whether neighboring municipalities resemble one another. First, a null model with no variables is estimated for our entire sample to test whether the residuals in Zeeland clustered geographically. Second, we estimate separate null models by sex to test whether geographic clustering of longevity differed by sex. Third, we test whether clustering of longevity changes over the life course. Four additional null models are estimated from which all individuals who died before age 5, 20, 30, or 50 are removed from the sample. Finally, we test whether we can explain why nearby places resemble one another by controlling for religion, soil type, population density, population size, net taxable income per capita, share of the labor force in agriculture, share of the labor force in trade, and the net migration rate. Effects are considered significant if the corresponding $p$-value is lower than 05 .

\subsection{Did longevity cluster in Zeeland}

Figure 3 shows the average chance to belong to the top 10\% survivors for the Zeeland municipalities. Scores are centred around the mean. Red tints indicate that inhabitants of a municipality had a below-average chance to belong to the top $10 \%$ survivors, whereas green tints show that inhabitants had an above-average chance to belong to the top $10 \%$ survivors. Differences in the chance to belong to the top $10 \%$ survivors are shown in terms of standard deviations. The darker the color, the stronger the deviation from the mean.

In most municipalities, individual chances to become long-lived diverged little from the mean. Nevertheless, there are multiple municipalities where the chance to belong to the top $10 \%$ survivors differs more than 1 standard deviation from the average chance to become in Zeeland. These municipalities are spread over the entire province. A small group of municipalities with low chances to belong to the top $10 \%$ survivors is located in southern Zuid-Beveland, whereas groups of municipalities with above-average chances to belong to the top $10 \%$ survivors are located in western Walcheren and on Schouwen. However, the Moran's I of .11 is not significant, which indicates that the resemblance between these neighbors is likely based in chance. 


\title{
Residuals Top 10\% - 0 model - all
}

\author{
Moran's I: 0.11
}

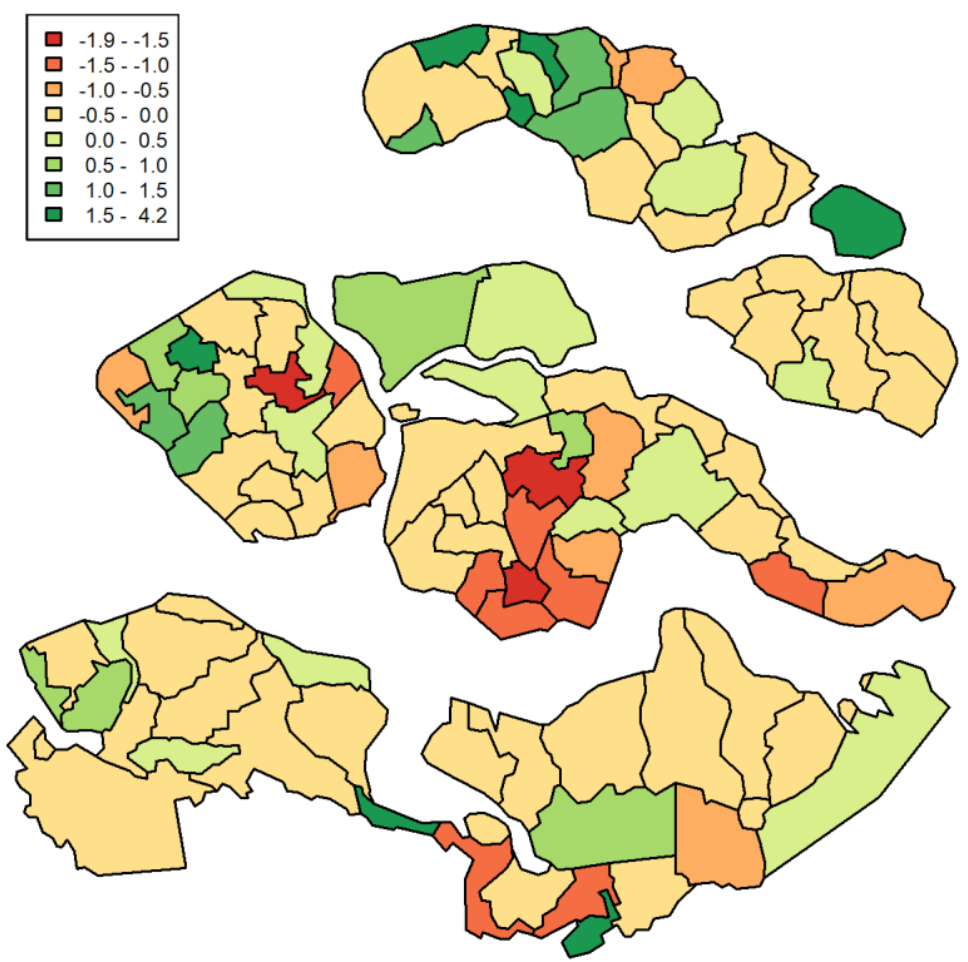

\subsection{Is the spatial clustering of longevity in Zeeland sex-specific?}

The average chance to belong to the top $10 \%$ survivors in each of the size Zeeland municipalities is shown by sex in Figure 4. Figure 4A shows that the chance to belong to the top $10 \%$ survivors is quite similar for women from neighboring municipalities. Although many observations are still centred around the mean, municipalities with a standard of more than 1 from the mean now neighbor each other. Municipalities with above-average chances to belong to the top $10 \%$ survivors are located on Schouwen and west Zeeuws-Vlaanderen, whereas municipalities with below-average chances to belong to the top $10 \%$ survivors are located in southern Zuid-Beveland. A Moran's I of .29 indicates that longevity clustered geographically for women in Zeeland.

There is little indication that longevity also clusters geographically for men. Municipalities where an usually high number of men belongs to the top $10 \%$ survivors are more spread over the island. Areas with below-average chances to belong to the top $10 \%$ survivors seem to be missing altogether, whereas there is a small group of municipalities with above-average chances to belong to the top $10 \%$ survivors in western Walcheren. The insignificant Moran's I of .09 indicates that there is no evidence of geographic clustering of longevity for men. 


\section{Residuals Top 10\% - 0 model - women}

Moran's I: 0.29

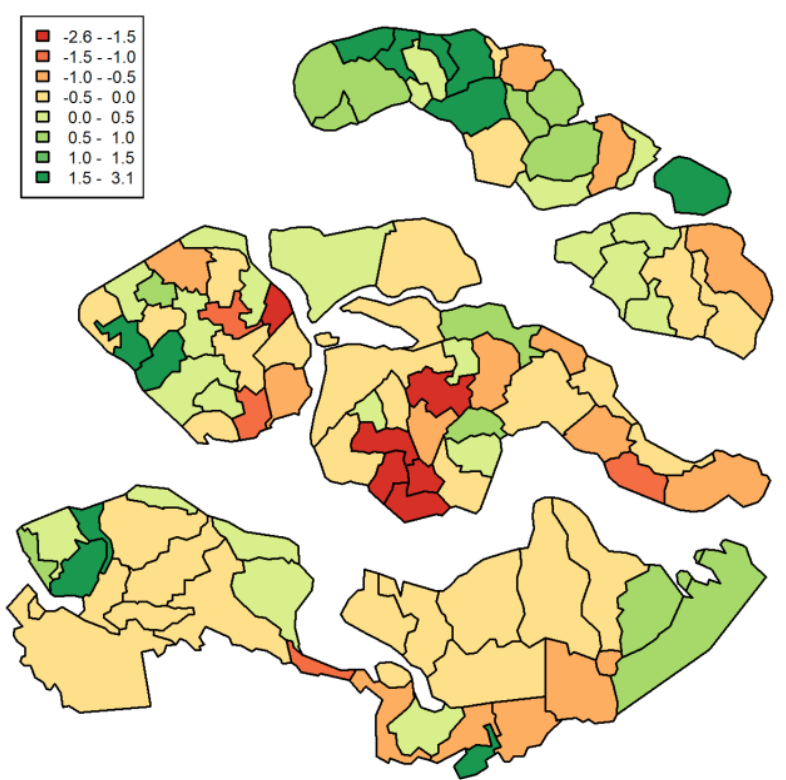

\section{Residuals Top $10 \%$ - 0 model - men}

Moran's I: 0.09
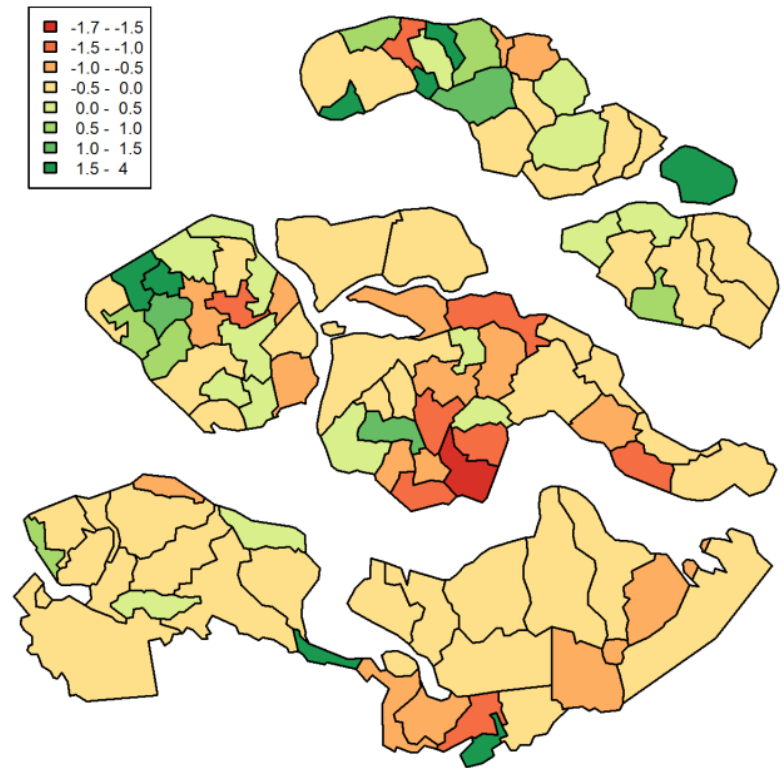

\subsection{Is the spatial clustering of longevity in Zeeland stable over time?}

Now that we have established that there is significant clustering for women, but not for men, we test if the clustering of longevity is stable over time. For both sexes, we estimated whether the chances to belong to the top $10 \%$ survivors in neighboring municipalities resembled each other more when we excluded mortality between ages $0-5,0-20,0-30$, and $0-50$. The outcomes of this procedure are shown in Table 2.

When we estimate chances to belong to the top $10 \%$ survivors from birth, we retrieved a Moran's I of . 29 for women. If we estimate the chance to belong to the top $10 \%$ survivors from ages 5 or 20 , the Moran's I increased slightly to .33. Estimating the chance to belong to the top $10 \%$ survivors from age 30 or 50 marginally increased the clustering of longevity further to .35 . Except for the first 5 years of life, clustering of longevity, thus, seems to be stable for women.

When we estimate the male chance to belong to the top $10 \%$ survivors from birth, the retrieved Moran's I is .09. This geographic clustering hardly changed if we used a different interval. Estimating male chances to belong to the top $10 \%$ survivors from age $5,20,30$, or 50 caused the Moran's I to vary between .08 and .12. Spatial correlations which were all insignificant. Also for men, the geographic clustering of the chance to belong to the top $10 \%$ survivors seems to be stable over time. 
Table 2: Moran's I index of clustering by sex

\begin{tabular}{l|ll|} 
& Women & Men \\
\hline 0 & .29 & .09 \\
5 & .33 & .09 \\
20 & .33 & .12 \\
30 & .35 & .09 \\
50 & .35 & .08
\end{tabular}

\subsection{Which environmental factors affect the clustering of longevity in Zeeland?}

In tables $3 \mathrm{a}$ and $3 \mathrm{~b}$ we explore to what extent the majority religion, dominant soil type, population density, number of inhabitants, net taxable income rate, percentage of the work force in agriculture or trade, and the net migration rate can explain geographic clustering of female and male chances to belong to the top $10 \%$ survivors. For each variable, we report the logit, standard deviation, and $\mathrm{p}$ value to indicate whether regression estimates had a significant positive or negative association with individual chances to belong to the top $10 \%$ survivors. The Moran's I after exclusion of the variable is used to indicate whether the variable explains geographic clustering of longevity. For the full model we report the Moran's I before and after inclusion of variables.

Table 3a shows that living that individuals living on clay had a better chance to belong to the top $10 \%$ survivors than individual living on sandy clay. Moreover, controlling for soil type reduced the spatial clustering. Besides living on clay soil, living in a larger municipality increased chances to belong to the top $10 \%$ survivors for women. This effect was weaker in the first years of life and did not explain clustering. The net taxable income per capita, share of the work force working in trade, and net migration rate were all negatively associated with female chances to belong to the top $10 \%$ survivors. Moreover, all variables explained clustering from age 5.

Table $3 \mathrm{~b}$ shows that men living on clay soils had better chances to belong to the top $10 \%$ survivors than men living on sandy clay soils. Especially in the first 5 years of life, this variable explained a large share of the - insignificant - clustering of longevity. Besides soil type, the share of the work force in agriculture was positively associated with male chances to belong to the top $10 \%$ survivors. However, the variable did not explain spatial clustering. Net taxable income per capita and the net migration rate were negatively associate with chances to belong to the top $10 \%$ survivors. Of these two variables, the net migration rate explained the - insignificant - clustering of longevity for men. 
Table 3a: Women

\begin{tabular}{|c|c|c|c|c|c|c|c|c|c|c|c|c|c|}
\hline & \multicolumn{4}{|c|}{0 - Top $10 \%$} & \multicolumn{3}{|c|}{$5-$ Top $10 \%$} & \multicolumn{3}{|c|}{$30-$ Top $10 \%$} & \multicolumn{3}{|c|}{$50-$ Top $10 \%$} \\
\hline & $\mathbf{N}$ & $\log +s d$ & p-value & Moran's I & $\log +s d$ & p-value & Moran's I & $\log +$ sd & p-value & Moran's I & $\log +\mathbf{s d}$ & p-value & Moran's I \\
\hline \multicolumn{14}{|l|}{ Religion } \\
\hline - liberal protestant & 52 & ref. & ref. & & ref. & ref. & & ref. & ref. & & ref. & ref. & \\
\hline - orthodox protestant & 19 & $.01(.07)$ & .930 & .05 & $-.04(.06)$ & .458 & .10 & $-.07(.06)$ & .218 & .13 & $-.09(.06)$ & .110 & .14 \\
\hline - roman catholic & 17 & $.07(.08)$ & .374 & .05 & $-.00(.06)$ & .973 & .10 & $.02(.06)$ & .728 & .13 & $.02(.06)$ & .701 & .14 \\
\hline - no dominant religion & 13 & $.01(.08)$ & .915 & .05 & $-.02(.07)$ & .759 & .10 & $-.03(.07)$ & .672 & .13 & $-.02(.07)$ & .743 & .14 \\
\hline \multicolumn{14}{|l|}{ Dominant soil type } \\
\hline - sandy clay & 75 & ref. & ref. & & ref. & ref. & & ref. & ref. & & ref. & ref. & \\
\hline - clay & 26 & $.16(.07)$ & .018 & .11 & $.11(.06)$ & .050 & .14 & $.13(.06)$ & .029 & .16 & $.11(.06)$ & .055 & .16 \\
\hline \multicolumn{14}{|l|}{ Population density } \\
\hline - <1000 p.ha. & 66 & ref. & ref. & & ref. & ref. & & ref. & ref. & & ref. & ref. & \\
\hline - 1000-2500 p.ha. & 28 & $.10(.07)$ & .184 & .01 & $.07(.06)$ & .245 & .07 & $.07(.06)$ & .268 & .09 & $.08(.06)$ & .173 & .10 \\
\hline - >4000 p.ha. & 7 & $-.20(.14)$ & .146 & .01 & $-.14(.12)$ & .226 & .07 & $-.13(.12)$ & .277 & .09 & $-.09(.12)$ & .438 & .10 \\
\hline Number of inhabitants & 101 & $.06(.04)$ & .204 & .05 & $.07(.04)$ & .060 & .11 & $.08(.04)$ & .029 & .14 & $.08(.04)$ & .034 & .14 \\
\hline Net taxable income p.c. & 101 & $-.03(.04)$ & .457 & .05 & $-.05(.03)$ & .083 & .16 & $-.07(.03)$ & .036 & .19 & $-.06(.03)$ & .044 & .19 \\
\hline$\%$ workforce in agriculture & 101 & $-.06(.05)$ & .281 & .03 & $-.01(.04)$ & .832 & .08 & $-.00(.04)$ & .954 & .12 & $.01(.04)$ & .898 & .13 \\
\hline$\%$ workforce in trade & 101 & $-.10(.03)$ & .002 & .15 & $-.07(.03)$ & .012 & .15 & $-.07(.03)$ & .015 & .16 & $-.07(.03)$ & .017 & .17 \\
\hline Net migration rate & 101 & $-.06(.03)$ & .015 & .06 & $-.07(.02)$ & .001 & .18 & $-.08(.02)$ & .000 & .22 & $-.08(.02)$ & .000 & .23 \\
\hline Moran's I: 0 model & & & & .29 & & & .33 & & & .35 & & & .35 \\
\hline Moran's I: full model & & & & .04 & & & .10 & & & .12 & & & .12 \\
\hline
\end{tabular}


Table 3b: Men

\begin{tabular}{|c|c|c|c|c|c|c|c|c|c|c|c|c|c|}
\hline & \multicolumn{4}{|c|}{0 - Top $10 \%$} & \multicolumn{3}{|c|}{$5-$ Top $10 \%$} & \multicolumn{3}{|c|}{$30-$ Top $10 \%$} & \multicolumn{3}{|c|}{$50-$ Top $10 \%$} \\
\hline & $\mathbf{N}$ & $\log +$ sd & p-value & Moran's I & $\log +s d$ & p-value & Moran's I & $\log +\mathbf{s d}$ & p-value & Moran's I & $\log +s d$ & p-value & Moran's I \\
\hline \multicolumn{14}{|l|}{ Religion } \\
\hline - liberal protestant & 52 & ref. & ref. & & ref. & ref. & & ref. & ref. & & ref. & ref. & \\
\hline - orthodox protestant & 19 & $.16(.06)$ & .005 & .04 & $.07(.04)$ & .094 & .03 & $.05(.04)$ & .251 & .02 & $.04(.04)$ & .320 & .02 \\
\hline - roman catholic & 17 & $.05(.06)$ & .403 & .04 & $-.06(.05)$ & .163 & .03 & $-.02(.05)$ & .697 & .02 & $.00(.05)$ & .936 & .02 \\
\hline - no dominant religion & 13 & $.03(.07)$ & .684 & .04 & $.00(.05)$ & .972 & .03 & $.01(.05)$ & .789 & .02 & $.02(.05)$ & .708 & .02 \\
\hline \multicolumn{14}{|l|}{ Dominant soil type } \\
\hline - sandy clay & 75 & ref. & ref. & & ref. & ref. & & ref. & ref. & & ref. & ref. & \\
\hline - clay & 26 & $.17(.06)$ & .002 & .01 & $.13(.04)$ & .002 & .00 & $.14(.04)$ & .002 & .03 & $.11(.05)$ & .013 & .02 \\
\hline \multicolumn{14}{|l|}{ Population density } \\
\hline - <1000 p.ha. & 66 & ref. & ref. & & ref. & ref. & & ref. & ref. & & ref. & ref. & \\
\hline - 1000-2500 p.ha. & 28 & $.06(.06)$ & .302 & -.05 & $.04(.04)$ & .311 & -.02 & $.03(.05)$ & .516 & .00 & $.03(.05)$ & .594 & .01 \\
\hline - >4000 p.ha. & 7 & $-.18(.12)$ & .118 & -.05 & $-.16(.08)$ & .057 & -.02 & $-.15(.09)$ & .084 & .00 & $-.12(.09)$ & .202 & .01 \\
\hline Number of inhabitants & 101 & $-.05(.04)$ & .162 & -.08 & $-.03(.03)$ & .262 & -.03 & $-.03(.03)$ & .301 & -.00 & $-.03(.03)$ & .303 & -.00 \\
\hline Net taxable income p.c. & 101 & $-.04(.03)$ & .157 & -.08 & $-.05(.02)$ & .031 & -.02 & $-.07(.02)$ & .006 & .01 & $-.07(.02)$ & .009 & .01 \\
\hline$\%$ workforce in agriculture & 101 & $.04(.05)$ & .376 & -.07 & $.08(.03)$ & .013 & -.02 & $.07(.03)$ & .037 & .01 & $.06(.03)$ & .054 & .01 \\
\hline \% workforce in trade & 101 & $-.06(.03)$ & .041 & -.00 & $-.04(.02)$ & .078 & .01 & $-.03(.02)$ & .224 & .02 & $-.02(.02)$ & .320 & .02 \\
\hline Net migration rate & 101 & $.02(.02)$ & .310 & -.07 & $-.04(.02)$ & .032 & -.00 & $-.05(.02)$ & .005 & .04 & $-.05(.02)$ & .009 & .05 \\
\hline Moran's I: 0 model & & & & .09 & & & .10 & & & .09 & & & .08 \\
\hline Moran's I: full model & & & & -.06 & & & -.02 & & & .01 & & & .01 \\
\hline
\end{tabular}


Figure 5: Clustering of individual chances to become long-lived in Zeeland after model correction, men and women

\section{Residuals Top 10\% - full model - women} Moran's I: 0.07
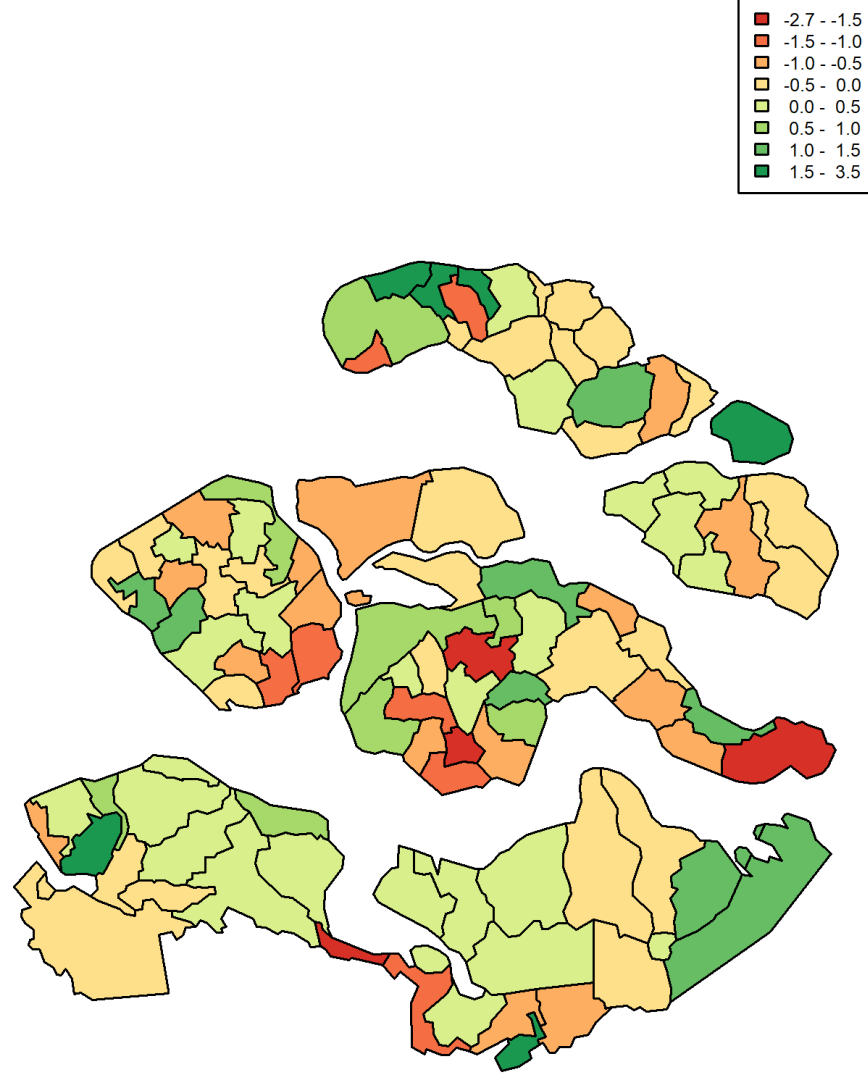

\section{Residuals Top 10\% - full model - men}

Moran's I: -0.08
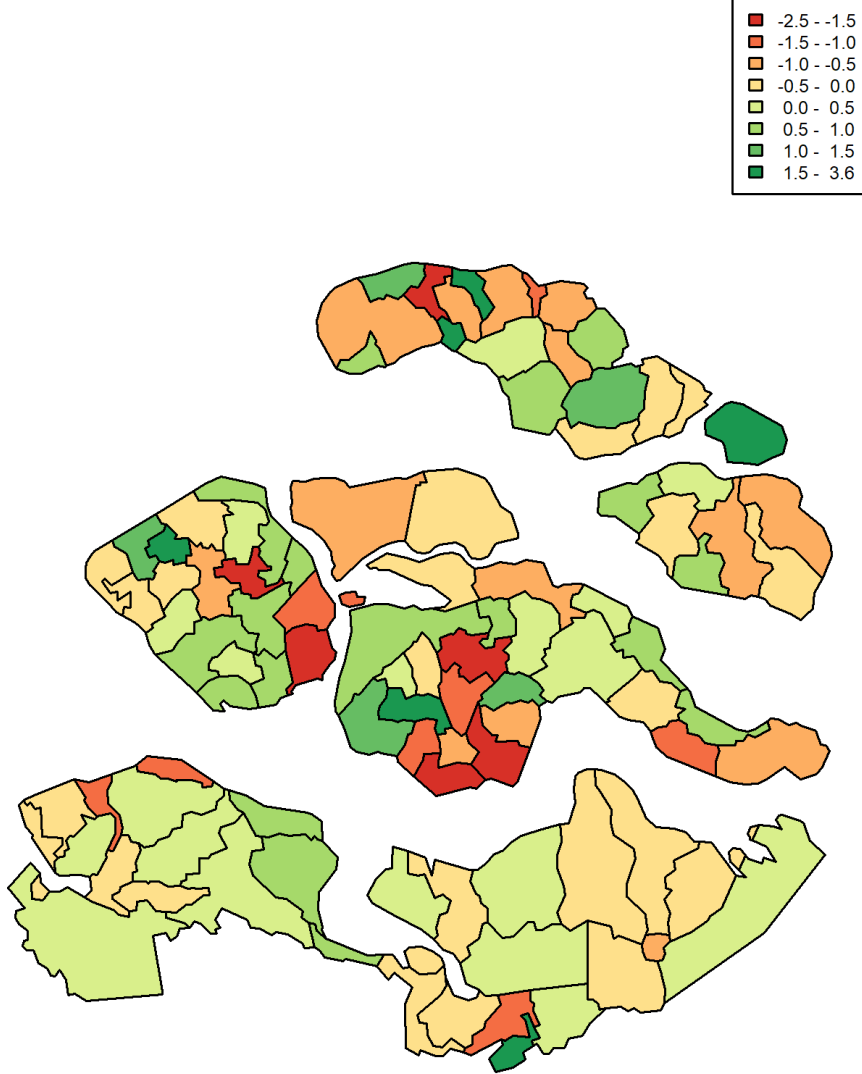


\section{Discussion}

Multiple studies on contemporary populations have shown that there are hotspots for longevity (Caselli \& Lipsi, 2006; Gavrilov \& Gavrilova, 2015; Montesanto et al., 2017; Pes et al., 2013; Poulain, Harm \& Pes, 2013; Roli et al., 2012; Rosero-Bixby, Dow \& Rehkopf, 2013). Yet, what exactly causes longevity to cluster and at which ages is less well understood. In this study, we explored whether: longevity clustered geographically, the geographic clustering of longevity was similar for men and women, clustering of longevity was constant over time, and geographic predictors of longevity could explain geographic clustering.

We found evidence of longevity clustering in Zeeland for women, while clustering was not significant for men. Still our analyses show that the geographic variables that affected individual chances to become long-lived were very similar for both sexes and in both cases was stable over time. The effects of the environment were also stable over the life course and not determined in early or later life. For both men and women, geographic clustering of longevity was dependent on soil type and net migration rate. For women, clustering of longevity further depended on the net taxable income per capita and share of the labor force working as a trader in a municipality. Furthermore, population size associated with female chances to become long-lived and net taxable income per capita associated with male chances to become long-lived, but did not explain geographic clustering. The effects of these variables were stable over the life course, further hinting at a continuous association between the living environment and offspring survival.

\subsection{Religion}

We found no relation between the majority religion in a municipality and an individual's chance to become long-lived. Historically, religion was associated with temperate lifestyles. Membership of close-knit religious groups - Mormons, Seventh-Day-Adventists, and Old Order Amish - has been associated with survival advantages due to abstaining from excess consumption of alcohol (Fraser, 1999; Hamman, Barancik \& Lilienfeld, 1981; Lindahl-Jacobsen et al., 2013; Temby \& Smith, 2014). Increased levels of social control have also been associated with differences in survival between mainstream denominations, as social control enforces more temperate lifestyles and stimulates networks of care and social support (Kok, 2017). Nevertheless, in our study inhabitants of municipalities in Zeeland with a Liberal Protestant, Roman Catholic or Orthodox Protestant majority all had the same chance to become long-lived.

Our findings contradict an earlier study on the relationship between religion and survival to advanced ages. Differences in survival after age 50 between Liberal Protestants and other religious denominations have been found for the Netherlands using microlevel data on religion and survival (Kok, 2017). There are three reasons why we might have missed this association between religion and individual chances to become long-lived. First, being Liberal Protestant meant something different in Zeeland than in the rest of the Netherlands. In the Netherlands, Liberal Protestant churches were highly secularized and enforced little control on their religious communities. In Zeeland, however, most of the Liberal Protestant churches were Ethisch Hervormd [Ethical Reformed] and, as such, not only embraced modernity and new cultural practices, but also valued tradition and the authority of the Bible (Knippenberg, 1992). As such, Liberal Protestant churches in Zeeland might have diverged less from the other denominations in terms of social control than elsewhere in the Netherlands. Second, because effects of belonging to a religious denomination were 
not measured on the individual level, we cannot rule out that religion had no effect on an individual's chances to become long-lived. It might be that the effect of belonging to a Liberal Protestant Church was too small to be picked up by our analyses. Third, differences between religious denominations in survival might exist between regions, but not within regions. In such cases, differences in survival are caused by regional cultures rather than religious communities. Therefore, additional individual-level studies are necessary to understand how religion affected human survival.

\subsection{Soil}

Generally, regional differences in survival have been explained by differences between clay and sand, i.e. fewer infectious diseases, more access to clean drinking water, and different agricultural traditions. According to these explanations, individuals living on clay should be less likely to become long-lived, as waterlogging clay soils are an excellent breeding ground for malaria mosquitos, soil water is more polluted, and large farms were worked by farm laborers rather than self-sufficient farmers (Devos \& Van Rossem, 2017; Hofstee, 1981). However, these explanations do not work within the context of Zeeland. Although the clay soils were excellent breeding grounds for malaria mosquitos and the soil was acid and saline in nature (Priester, 1998), inhabitants of clay soils had a better chance to become long-lived than inhabitants of sandy clay. It might be that inhabitants of the clay soils live longer, due to how the land is used. Agriculture was less common on the clay soils, because the high salinity and acidity of the soil made it hard to grow crops. Hence, farmers held more stock. Just like in Holland, farmer's wives took this opportunity to produce cheese. This may have provided these households with some extra income (Van Cruyningen, 2005). Furthermore, farmers on clay soil worked less land than the farmers on sandy clay. This means that the ratio between farmers and farm workers is lower (Priester, 1998), so that more people had their own land which they could work on. Farmers were more secure of income than farm workers, which might have benefited their survival.

A strong focus on agriculture seems to be good for men, while it has no effect on female chances to become long-lived. This is most likely not related to environmental effects, but to the characteristics of the inhabitants, as farmers are known to live longer than any other occupational group (Edvinsson \& Broström, 2012; Ferrie, 2003; Gagnon et al., 2011; Mourits et al., 2018; Schenk \& van Poppel, 2011; Temby \& Smith, 2014). Whether non-farmers also profited from living in a municipality with a focus on farming is uncertain, but there is no reason to assume so. Living in a wealthier municipality seemed to be detrimental for men as well as women, due to the higher inequalities in the municipality. The wealthier municipalities were not the cities, but transport hubs or farmland near Goes and Middelburg. Most likely a focus on cash crops and large-scale farming, meant that a smaller number of farmers employed a larger number of farm laborers. These farm laborers did not have their own land to build and were more dependent on the market for access to food. Hence, the association between soil and human survival might be dependent on an individual's chances to have one's own farm, which assured better access to food for both men and women.

\subsection{Urbanization}

City size had a positive influence on a woman's chances to become long-lived, whereas no association was found for men. This is in line with the idea that the countryside was healthy for men as they did not work in poorly ventilated workshops and spent less time in the pub, whereas cities 
were healthy for women due to more positive gender roles (Janssens, Messelink \& Need, 2010; Reher, 2001). However, our findings contradict urban mortality penalties that have been found for cities in the Netherlands (Drukker \& Tassenaar, 1997; Nederlandsche Maatschappij tot Bevordering der Geneeskunst, 1879) and other countries in Western Europe (see e.g. Eggerickx \& Debuisson, 1990; Kesztenbaum \& Rosenthal, 2011; Vögele, 1998). There are two explanations why we do not find evidence of an early penalty in Zeeland. First of all, Zeeland never urbanized as strongly as other Western European regions. Rising metropoles like Rotterdam or Antwerp were just outside the municipal borders and the larger town in Zeeland did not suffer from the negative effects of overcrowding which came with large levels of immigration. Hence, municipality size in Zeeland was not related to the strong negative effects that larger cities in Western Europe experienced. Second, the positive association between living in a larger town and individual chances on becoming longlived were only found after controlling for soil type, net taxable income per capita, and the percentage of traders in the work force. This is in line with more recent studies on mortality after age 50 in Utah and Québec (Gagnon et al., 2009; Temby \& Smith, 2014). These studies showed that after controlling for other factors, living in a larger town was beneficial for survival. This is in line with the debate on human stature, which found evidence of both urban penalties and urban premiums (Reis, 2009). Therefore, we conclude that living in larger towns also had its benefits, which has received little attention in the historical research due to our focus on the urban mortality penalty.

The net migration rate distinguishes between regions with little migration, some outmigration, and more outmigration. Earlier studies have shown that migrants on average live longer than stayers (Alter \& Oris, 2005; Puschmann, Donrovich \& Matthijs, 2017; Van den Berg, Van Dijk, Mourits, et al., 2018). Nevertheless, our results show that individuals from municipalities with net outmigration had a higher chance to become long-lived. It is unlikely that the negative relationship between the migration rate and chance to become long-lived is attributable to compositional effects, as high outmigration of the healthiest inhabitants makes the remaining population less likely to become long-lived. Moreover, immigration and emigration are not related to an individual's chances to become long-lived (correlations between the share of long-lived individuals and immigration/emigration rates are -.11 and -.10, respectively). Most likely the association between the net migration and individual chances to become long-lived are attributable to demographic pressure. There was no room for spatial or demographic expansion in Zeeland, as there was no land acquisition during the $19^{\text {th }}$ century and the economy did not grow. Outmigration from Zeeland relieved the demographic pressure on Zeeland and left better economic opportunities for those who stayed behind. Moreover, it is to be expected that the individuals who left were least likely to attain a good position in society. Therefore, small levels of net outmigration already had a notable effect on local communities.

Our analyses also showed that trade has a negative effect on female survival. The more traders there are in a municipality, the lower the chance for someone to become long-lived. It is not possible to determine whether this effect is also present for men, as effects of farming and trade are multicollinear. The positive effect of living in a town with many farmers in the work force is so strong and robust for men that they negate the possible effects of the share of traders in the work force. Nevertheless, the share of traders in the work force had a significant binomial relationship with individual chances to become long-lived, indicating that there might also be an association between trade and male chances to become long-lived. 
There are multiple explanations why the share of traders in a municipality correlates with (female) chances to become long-lived. First, the share of the workforce in trade might be indicative for effects of urbanization in general, as the variable identifies the municipalities that function as regional centers on the Zeeland islands. However, it is unlikely that urbanization in Zeeland decreased individual chances to become long-lived. Zeeland never really industrialized in the $19^{\text {th }}$ century and most of the pockets of industrialization were focused on mechanization of the countryside, rather than the cities (Zijdeman, 2010). Furthermore, little overcrowding occurred (Hoogerhuis, 2003) and our analyses showed that population density had no effect on offspring survival. Moreover, because the share of traders in a province explains a significant part of longevity clustering, it is unlikely that it is a proxy for another geographic effect that was also included in our regression models. Second, it might be that the share of the workforce in trade is a proxy for work in another sector. Especially work in the cottage industry has been shown to be detrimental for survival (Van Rossem, Deboosere \& Devos, 2017). However, a closer inspection of our data - as shown in Table A2 - shows that the share of workers in labor is not correlated to work in any other major sector in Zeeland. As such, a municipal focus on trade cannot be a proxy for work in another economic sector. A third explanation, is that the most unfortunate worked in trade as a last resort to secure oneself of some income. These individuals might have been hucksters, peddlers, and petty merchants that catered to the rural populations on the island. In Zeeland, traders mainly lived along the canals on Walcheren or in the island centers (see Figure A8), which were ideal locations to buy goods and later sell them in the surrounding countryside. These small traders are known to have been insecure of food and income. Poverty might explain why living in a place with traders is bad for survival to exceptional ages. Earlier studies have shown that small entrepreneurs show higher mortality in later life (Edvinsson \& Broström, 2012; Mourits, Smith \& Janssens, 2018). Therefore, the effects of trading on the chance to become long-lived are most likely a composition effect.

To substantiate our hypothesis, we took a further look at the 1930 census from which we derived our information on the share of traders in the work force. Aggregate information on the number of owners, managers, foremen, and laborers working in trade were available on the provincial level. Supplementary Table A4 shows that traders usually worked alone, although some also had personnel. This is in favor of our argument that most of the traders were petty merchants. The 1930 census further included aggregated information on what the Zeeland traders sold. As shown in Table A5, $40 \%$ of trade occurred in wholesale, distributive trade, and retail. This is a wide range of activities from which it is hard to conclude who these traders were. However, another $40 \%$ of the traders worked as a peddler, grocer, or cloth salesman. None of these individuals produced their own goods and instead sold goods of relatively low value. The low profits that could be gained on these products probably made these individuals among the poorest in Zeeland. Hence, living in a town with a focus on trade might be synonymous with living in a town with increased levels of poverty. When a sizable share of the work force was a huckster, peddler, or petty merchant - and, thus, lived in poverty - it is to be expected that this had its effects on the overall chances to become long-lived.

\section{Conclusion}

We found evidence of a well-established connection between the living environment and mortality. During the $19^{\text {th }}$ century, effects of the environment on mortality seemed much stronger than effects of social class, which are more prominent today. Earlier studies have concluded that the environment is one of the main determinants for levels of child mortality. The frameworks necessary for explaining 
why longevity clusters are to a large extent already available in the historical literature. Not only do these environmental factors affect individual chances to become long-lived, they also explain why longevity clusters geographically. Nearby places often resemble each other in agricultural focus and demographic pressure. This makes it seem like some living environments are healthier than other environments, but mortality levels are to a large extent caused by human behavior. Hence, longevity clustering at the regional level does not seem to be caused by favorable genetic predispositions or direct influences by the environment itself.

Geographic clustering is but one tool to further understand the relationship between the environment and longevity. Studies on clustering can identify places where more people became long-lived. However, geographic clustering of longevity only shows that certain environments stimulated specific behavior. A cluster indicates that nearby municipalities or individuals share a similar characteristic which is beneficial or detrimental to human survival. The effects of such an environmental characteristic can also be modelled without focusing on clustering, as long as models are corrected for spatial autocorrelation. This is considered good practice in the study of infant and child mortality (see e.g. Jaadla \& Reid, 2017; van den Boomen \& Rotering, 2018). Hence, both theoretically and methodologically the study of environmental influences on longevity can learn a lot from the existing work on the historical demographic studies on infant and child mortality.

\section{Literature}

Alter, G., Dribe, M., \& Van Poppel, F. W. A. (2007). Widowhood, family size, and postreproductive mortality: A comparative analysis of three populations in nineteenth-century Europe. Demography, 44(4), 785-806. https://doi.org/10.1353/dem.2007.0037

Alter, G., \& Oris, M. (2005). Childhood conditions, migration, and mortality: Migrants and natives in 19th century cities. Biodemography and Social Biology, 52(3-4), 178-191. https://doi.org/10.1080/19485565.2005.9989108

Beekink, E., Boonstra, O., Engelen, T., \& Knippenberg, H. (2003). De Historische Databank Nederlandse Gemeenten (HDNG): Een nieuw hulpmiddel voor de bestudering van een samenleving in transformatie. In Nederland in verandering: Maatschappelijke veranderingen in kaart gebracht 1800-2000 (pp. 169-174). Amsterdam: Aksant Academic Publishers.

Boonstra, O. W. A. (2007). NLGis shapefiles. DANS. https://doi.org/http://dx.doi.org/10.17026/dans$\mathrm{xb9-t677}$

Bras, H. (2002). Zeeuwse meiden: Dienen in de levensloop van vrouwen, ca. 1850-1950. Amsterdam: Aksant.

Caselli, G., \& Lipsi, R. M. (2006). Survival differences among the oldest old in Sardinia: Who, what, where, and why. Demographic Research, 14, 267-294. https://doi.org/10.4054/DemRes.2006.14.13

De Kanter, J., \& Utrecht-Dresselhuys, J. A. B. (1824). De provincie Zeeland. Middelburg: Gebr. Abrahams.

Departement van Financiën. (1869). Statistiek van het Koninkrijk der Nederlanden: Bescheiden betreffende de geldmiddelen. 's-Gravenhage: Martinus Nijhoff.

Devos, I., \& Van Rossem, T. (2017). Oud, ouder, oudst: Regionale en lokale verschillen in sterfte in het graafschap Vlaanderen tijdens de zeventiende en achttiende eeuw. De Zeventiende Eeuw, 1, 39-53.

Drukker, J. W., \& Tassenaar, V. (1997). Paradoxes of modernization and material well-being in the Netherlands during the nineteenth century. Health and Welfare during Industrialization.

Edvinsson, S., \& Broström, G. (2012). Old age, health, and social inequality: Exploring the social patterns of mortality in 19th century northern Sweden. Demographic Research, 26, 633-660. https://doi.org/10.4054/DemRes.2012.26.23 
Eggerickx, T., \& Debuisson, M. (1990). La surmortalité urbaine: Le cas de la Wallonie et de Bruxelles à la fin du XIXe siècle (1889-1892). Annales de Démographie Historique, 23-41.

Ferrie, J. P. (2003). The Rich and the Dead: Socioeconomic Status and Mortality in the United States, 1850-1860. In D. L. Costa (Ed.), Health and Labor Force Participation over the Life Cycle: Evidence from the Past (pp. 11-50). Chicago: University of Chicago Press. Retrieved from http://ideas.repec.org/h/nbr/nberch/9627.html

Fraser, G. E. (1999). Associations between diet and cancer, ischemic heart disease, and all- cause mortality in non-Hispanic white California Seventh-day Adventists. American Journal of Clinical Nutrition, 70(3 SUPPL.), 532-538. https://doi.org/10.1093/ajcn/70.3.532s

Gagnon, A., Smith, K. R., Tremblay, M., Vézina, H., Paré, P.-P., \& Desjardins, B. (2009). Is there a trade-off between fertility and longevity? A comparative study of women from three large historical databases accounting for mortality selection. American Journal of Human Biology, 21(4), 533-540. https://doi.org/10.1002/ajhb.20893

Gagnon, A., Tremblay, M., Vézina, H., \& Seabrook, J. A. (2011). Once were farmers: Occupation, social mobility, and mortality during industrialization in Saguenay-Lac-Saint-Jean, Quebec 1840-1971. Explorations in Economic History, 48(3), 429-440. https://doi.org/10.1016/j.eeh.2011.05.008

Gavrilov, L. A., \& Gavrilova, N. S. (2015). New Developments in the Biodemography of Aging and Longevity. Gerontology, 61(4), 364-371. https://doi.org/10.1159/000369011

Hamman, R. F., Barancik, J. I., \& Lilienfeld, A. M. (1981). Patterns of mortality in the Old Order Amish: I. Background and major causes of death. American Journal of Epidemiology, 114(6), 845-861.

Hedefalk, F., Quaranta, L., \& Bengtsson, T. (2017). Unequal lands: Soil type, nutrition, and child mortality in southern Sweden, 1850-1914. Demographic Research, 36(1), 1039-1080. https://doi.org/10.4054/DemRes.2017.36.36

Hermsen, T. (2018). Zeeland islands and municipalities. Humanities Lab, Faculty of Arts, Radboud University.

Hofstee, E. W. (1981). Korte demografische geschiedenis van Nederland van 1800 tot heden. Haarlem: Fibula-Van Dishoeck.

Hofstee, E. W. (1983). Geboorten, zuigelingenvoeding en zuigelingensterfte in hun regionale verscheidenheid in de 19de eeuw. Bevolking En Gezin, (2), 7-60.

Hoogerhuis, O. W. (2003). Baren op Beveland: Vruchtbaarheid en zuigelingensterfte in Goes en omliggende dorpen gedurende de 19e eeuw. Wageningen: Wageningen Universiteit.

Human Mortality Database. (2018). Human Mortality Database. Retrieved from www.mortality.org or www.humanmortality.de

Jaadla, H., \& Reid, A. (2017). The geography of early childhood mortality in England and Wales, 18811911. Demographic Research, 37(1), 1861-1890. https://doi.org/10.4054/DemRes.2017.37.58

Janssens, A., Messelink, M., \& Need, A. (2010). Faulty genes or faulty parents? Gender, family and survival in early and late childhood in the Netherlands, 1860-1900. The History of the Family, 15(1), 91-108. https://doi.org/10.1016/j.hisfam.2010.01.005

Kesztenbaum, L., \& Rosenthal, J.-L. (2011). The health cost of living in a city: The case of France at the end of the 19th century. Explorations in Economic History, 48(2), 207-225. https://doi.org/10.1016/j.eeh.2010.12.002

Knippenberg, H. (1992). De religieuze kaart van Nederland: Omvang van geografische spreiding van de godsdienstige gezindten vanaf de Reformatie tot heden. Assen: Van Gorcum.

Koenig, H. G., King, D. E., \& Carson, V. B. (2012). Handbook of religion and health (Second edi). Oxford: Oxford University Press.

Kok, J. (1997). Youth labor migration and its family setting, the Netherlands 1850-1940. History of the Family, 2(4), 507-526. https://doi.org/10.1016/S1081-602X(97)90027-0

Kok, J. (2017). Church affiliation and life course transitions in The Netherlands, 1850-1970. Historical Social Research, 42(2), 59-91. https://doi.org/10.12759/hsr.42.2017.2.

Lindahl-Jacobsen, R., Hanson, H. A., Oksuzyan, A., Mineau, G. P., Christensen, K., \& Smith, K. R. (2013). The male-female health-survival paradox and sex differences in cohort life expectancy in Utah, Denmark, and Sweden 1850-1910. Annals of Epidemiology, 23(4), 161-166. 
https://doi.org/10.1016/j.annepidem.2013.02.001

Mandemakers, K., \& Laan, F. (2017). LINKS dataset Genes Germs and Resources, WieWasWie Zeeland, Civil Certificates, version 2017.01 [Data file and code book]. Amsterdam: IISH.

Ministerie van Binnenlandse Zaken. (1875). Verslag van den landbouw in Nederland: Grootte der gronden tijdens de invoering van het kadaster. 's-Gravenhage: Van Weelden en Mingelen.

Montesanto, A., De Rango, F., Pirazzini, C., Guidarelli, G., Domma, F., Franceschi, C., \& Passarino, G. (2017). Demographic, genetic and phenotypic characteristics of centenarians in Italy: Focus on gender differences. Mechanisms of Ageing and Development, 165(April), 68-74. https://doi.org/10.1016/j.mad.2017.04.008

Mourits, R. J., Smith, K. R., \& Janssens, A. (2018). Were the wealthier always healthier? Diverging effects of socioeconomic status on later-life mortality in two historical populations, 1862-2000. Unpublished Manuscript.

Munro, L. J. A., Penning-Rowsell, E. C., Barnes, H. R., Fordham, M. H., \& Jarrett, D. (1997). Infant mortality and soil type: A case study in south-central England. European Journal of Soil Science, 48(1), 1-11. https://doi.org/10.1111/j.1365-2389.1997.tb00179.x

Nederlandsche Maatschappij tot Bevordering der Geneeskunst. (1879). Sterfte-atlas van Nederland. Amsterdam: Van Rossen. Retrieved from http://imagebase.ubvu.vu.nl/cdm/ref/collection/krt/id/4796

Pes, G. M., Tolu, F., Poulain, M., Errigo, a., Masala, S., Pietrobelli, a., ... Maioli, M. (2013). Lifestyle and nutrition related to male longevity in Sardinia: An ecological study. Nutrition, Metabolism and Cardiovascular Diseases, 23(3), 212-219. https://doi.org/10.1016/j.numecd.2011.05.004

Poulain, M., Herm, A., \& Pes, G. (2013). The Blue Zones: Areas of exceptional longevity around the world. Vienna Yearbook of Population Research, 11, 87-108.

Priester, P. (1998). Geschiedenis van de Zeeuwse landbouw circa 1600-1910. Wageningen: Landbouwuniversiteit Wageningen.

Puschmann, P., Donrovich, R., \& Matthijs, K. (2017). Salmon Bias or Red Herring?: Comparing Adult Mortality Risks (Ages 30-90) between Natives and Internal Migrants: Stayers, Returnees and Movers in Rotterdam, the Netherlands, 1850-1940. Human Nature, 28(4), 481-499. https://doi.org/10.1007/s12110-017-9303-1

Reher, D. S. (2001). Mortality Patterns in Spain Transition. International Journal of Population Geography, 7, 105-127. https://doi.org/10.1002/ijpg.212

Reis, J. (2009). "Urban Premium » or "Urban Penalty »? The Case of Lisbon , 1840-1912. Historia Agraria, 47(April), 69-94.

Ribeiro, A. I., Krainski, E. T., Carvalho, M. S., \& de Pina, M. de F. (2016). Where do people live longer and shorter lives? An ecological study of old-age survival across 4404 small areas from 18 European countries. Journal of Epidemiology and Community Health, 70(6), 561-568. https://doi.org/10.1136/jech-2015-206827

Roli, G., Samoggia, A., Miglio, R., \& Rettaroli, R. (2012). Longevity pattern in the Italian region of Emilia Romagna: A dynamic perspective. Geospatial Health, 6(2), 233-245. https://doi.org/10.4081/gh.2012.141

Rosero-Bixby, L., Dow, W. H., \& Rehkopf, D. H. (2013). The Nicoya region of Costa Rica: A high longevity island for elderly males. Vienna Yearbook of Population Research, 11, 109-136.

Schenk, N., \& van Poppel, F. (2011). Social class, social mobility and mortality in the Netherlands, 1850-2004. Explorations in Economic History, 48(3), 401-417. https://doi.org/10.1016/j.eeh.2011.05.010

Smith, K. R., Gagnon, A., Cawthon, R. M., Mineau, G. P., Mazan, R., \& Desjardins, B. (2009). Familial aggregation of survival and late female reproduction. The Journals of Gerontology Series A: Biological Sciences and Medical Sciences, 64(7), 740-744. https://doi.org/10.1093/gerona/glp055

Temby, O. F., \& Smith, K. R. (2014). The association between adult mortality risk and family history of longevity: The moderating effects of socioeconomic status. Journal of Biosocial Science, 46(6), 703-716. https://doi.org/10.1017/S0021932013000515 
Van Cruyningen, P. (2005). Vrouwenarbeid in de zeeuwse landbouw in de achttiende eeuw. Tijdschrift Voor Sociale En Economische Geschiedenis, 2(3), 43-59.

Van den Berg, N., Rodriguez-Girondo, M., Van Dijk, I.K., Mourits, R.J., Mandemakers, K., Janssens, A., Beekman, M., Smith, K.R. \& Slagboom, P. E. (2019). Longevity defined as top $10 \%$ survivors is transmitted as a quantitative genetic trait. Nature Communications, 10(1). https://doi.org/10.1038/s41467-018-07925-0

Van den Berg, N., Van Dijk, I. K., Mourits, R. J., Janssens, A., Slagboom, P. E., \& Mandemakers, K. (2018). Families in comparison: An individual-level comparison of life course and family reconstructions between population and vital event registers. SocArXiv. https://doi.org/10.31235/osf.io/h2w8t

van den Boomen, N., \& Ekamper, P. (2015). Denied their 'natural nourishment': Religion, causes of death and infant mortality in the Netherlands, 1875-1899. The History of the Family, 20(2), 129. https://doi.org/10.1080/1081602X.2015.1022199

van den Boomen, N., \& Rotering, P. (2018). The regionality of infant mortality in the Netherlands, 1875-1899. Unpublished Manuscript.

Van der Kaaden, J. J. (2003). Geschiedenis van de inheemse malaria in Nederland. Infectieziekten Bulletin, 14(10), 388-393.

Van der Meer, A., \& Boonstra, O. W. A. (2006). Repertorium van Nederlandse gemeenten, 1812-2006. Den Haag: DANS - Data Archiving and Networked Services.

Van der Woud, A. (2010). Koninkrijk vol sloppen: Achterbuurten en vuil in de negentiende eeuw. Amsterdam: Bert Bakker.

Van Dijk, I. K., Janssens, A., \& Smith, K. R. (2018). The long harm of childhood: Childhood exposure to mortality and subsequent risk of adult mortality in Utah and the Netherlands. European Journal of Population, (0123456789). https://doi.org/10.1007/s10680-018-9505-1

Van Dijk, I. K., \& Mandemakers, K. (2018). Like mother, like daughter. Intergenerational transmission of infant mortality clustering in Zeeland,the Netherlands, 1833-1912. Historical Life Course Studies, 5. Retrieved from http://www.ehps-net.eu/article/intermediate-data-structure-idslongitudinal-historical-microdata-version-

4/hislives_vol_1_03_07_14.pdf\%5Cnhttp://hdl.handle.net/10622/23526343-20140001 ?locatt=view:master

Van Leeuwen, M. H. D., \& Maas, I. (2007). Economische specialisering en veranderende sociale verhoudingen in de 19e en 20e eeuw: Een studie op basis van de Nederlandse volkstellingen en huwelijksakten. In Twee eeuwen Nederland geteld: Onderzoek met de digitale volks-, beroepsen woningtellingen, 1795-2001 (pp. 181-205). Den Haag: DANS - Data Archiving and Networked Services.

van Poppel, F., Ekamper, P., \& Mandemakers, K. (2018). Season of birth and early childhood mortality: A review of the debate and a case study for the Netherlands, 1812-1912. In P. Puschmann \& T. Riswick (Eds.), Building bridges: Scholars, history, and historical demography (pp. 590-525). Nijmegen: Valkhof Pers.

Van Rossem, T., Deboosere, P., \& Devos, I. (2017). Death at work? Mortality and industrial employment in Belgian cities at the turn of the twentieth century. Explorations in Economic History, 66(October), 44-64. https://doi.org/10.1016/j.eeh.2017.08.006

Vögele, J. (1998). Urban Mortality Change in England and Germany, 1870-1913. Liverpool: Liverpool University Press.

Voland, E., \& Dunbar, R. I. M. (1995). Resource competition and reproduction: The relationship of economic and parental strategies in the Krummhörn population (1720-1874). Human Nature, 6(1), 33-49.

Wolleswinkel-van den Bosch, J. H., Van Poppel, F. W. A., Looman, C. W. N., \& Mackenbach, J. P. (2001). The role of cultural and economic determinants in mortality decline in the Netherlands, 1875/1879-1920/1924: A regional analysis. Social Science and Medicine, 53(11), 1439-1453. https://doi.org/10.1016/S0277-9536(00)00417-2

WUR-Alterra. (2006). Dataset grondsoortenkaart van Nederland 2006. Wageningen. 
Zijdeman, R. (2010). Status attainment in the Netherlands, 1811-1941: Spatial and temporal variation before and during industrialization. Universiteit Utrecht.

Zimmer, Z., Hanson, H. A., \& Smith, K. R. (2016). Offspring socioeconomic status and parent mortality within a historical population. Demography, 53(5), 1583-1603. https://doi.org/10.1007/s13524016-0502-x 


\section{Appendix}

Table A1: Religious denominations in Zeeland

\begin{tabular}{lrrr} 
Denomination & N & perc & ministers \\
\hline Dutch Reformed & 120,461 & 67.8 & \\
- Liberal & & & $12.3 \%$ \\
- Ethical & & & $59.4 \%$ \\
- Confessional / Reformed & & & $28.3 \%$ \\
Reformed & 8,289 & 4.7 & \\
Roman-Catholic & 46,046 & 25.9 & \\
Other & 2,773 & 1.6 & \\
\hline Total & 177,569 & 100 &
\end{tabular}

Table A2: Largest industries in Zeeland in 1920 occupational census

\begin{tabular}{lrr} 
Sector & N & \multicolumn{1}{c}{ Perc } \\
\hline Landbouwbedrijven & 33749 & $42,8 \%$ \\
Verkeerswezen & 8255 & $10,5 \%$ \\
Bouwbedrijven, enz. & 6916 & $8,8 \%$ \\
Handel & 6800 & $8,6 \%$ \\
Metaalnijverheid, scheeps- en rijtuigbouw & 5763 & $7,3 \%$ \\
Bereiding van voedings- en genotsmiddelen & 4232 & $5,4 \%$ \\
Visserij en jacht & 1634 & $2,1 \%$ \\
Overig (<2\% van beroepsbevolking) & 11500 & $14,6 \%$ \\
\hline Totale beroepsbevolking & $\mathbf{7 8 8 4 9}$ & $\mathbf{1 0 0 , 0 \%}$
\end{tabular}

Table A3: Correlation between size of agriculture/trade and other prominent sectors

\begin{tabular}{lrr} 
Sector & landbouw & handel \\
\hline Landbouwbedrijven & 1.00 & -.71 \\
Verkeerswezen & -.43 & .38 \\
Bouwbedrijven, enz. & -.40 & .21 \\
Handel & -.71 & 1.00 \\
Metaalnijverheid, scheeps- en rijtuigbouw & -.70 & .12 \\
Voedings- en genotmiddelen & -.55 & .37 \\
Visserij & -.40 & .08
\end{tabular}


Table A4: Position within the trading business

\begin{tabular}{lrr} 
Omschrijving & N & Perc \\
\hline Eigenaar & 3971 & $58,4 \%$ \\
Manager & 56 & $0,8 \%$ \\
Bedrijfsleider / voorman & 220 & $3,2 \%$ \\
Arbeider & 1138 & $16,7 \%$ \\
Niet behorende tot eigenlijke bedrijf & 1415 & $\mathbf{2 0 , 8 \%}$ \\
\hline Totaal aantal handelaren & $\mathbf{6 8 0 0}$ & $\mathbf{1 0 0 , 0 \%}$ \\
& Source: 1930 census
\end{tabular}

Table A5: Most prominent trading businesses

\begin{tabular}{lrr} 
Omschrijving & N & \multicolumn{1}{c}{ Perc } \\
\hline Groot-, tusschen- en detailhandel & 2743 & $40,3 \%$ \\
Venters en opkoopers & 1186 & $17,4 \%$ \\
Kruidenierswaren & 959 & $14,1 \%$ \\
Kleeding en modeart. & 542 & $8,0 \%$ \\
Overig (<2\% van handel) & 1370 & $20,1 \%$ \\
\hline Totaal aantal handelaren & $\mathbf{6 8 0 0}$ & $\mathbf{1 0 0 , 0 \%}$
\end{tabular}


Table A6: Number of observations per municipality

\begin{tabular}{|c|c|c|c|c|c|}
\hline Municipality & $\mathbf{N}$ & Municipality & $\mathbf{N}$ & Municipality & $\mathbf{N}$ \\
\hline Aagtekerke & 524 & Kattendijke & 935 & 's-Heerenhoek & 863 \\
\hline Aardenburg & 2946 & Kerkwerve & 747 & Sas van Gent & 560 \\
\hline Arnemuiden & 2793 & Kloetinge & 1379 & Scherpenisse & 1531 \\
\hline Axel & 3880 & Koewacht & 1489 & Schoondijke & 1920 \\
\hline Baarland & 782 & Kortgene & 4883 & Serooskerke (Schouwen) & 335 \\
\hline Biervliet & 2313 & Koudekerke (Walcheren) & 2038 & Serooskerke (Walcheren) & 1530 \\
\hline Biggekerke & 772 & Krabbendijke & 1317 & Sint Annaland & 2436 \\
\hline Borssele & 1202 & Kruiningen & 2061 & Sint Jansteen & 1283 \\
\hline Breskens & 1577 & Meliskerke & 713 & Sint Laurens & 699 \\
\hline Brouwershaven & 1485 & Middelburg & 12405 & Sint Maartensdijk & 2661 \\
\hline Bruinisse & 1971 & Nieuw- en Sint Joosland & 1114 & Sint Philipsland & 917 \\
\hline Burgh & 741 & Nieuwerkerk (Duiveland) & 1250 & Sluis & 2276 \\
\hline Cadzand & 1324 & Nieuwvliet & 921 & Stavenisse & 1752 \\
\hline Clinge & 830 & Nisse & 656 & Terneuzen & 3076 \\
\hline Domburg & 1147 & Noordgouwe & 794 & Tholen & 2809 \\
\hline Dreischor & 1194 & Noordwelle & 562 & Veere & 998 \\
\hline Driewegen & 685 & Oost- en West-Souburg & 1408 & Vlissingen & 5513 \\
\hline Duivendijke & 568 & Oostburg & 1820 & Vogelwaarde & 3845 \\
\hline Elkerzee & 525 & Oosterland & 1602 & Vrouwenpolder & 1278 \\
\hline Ellemeet & 450 & Oostkapelle & 1101 & Waarde & 953 \\
\hline Ellewoutsdijk & 1020 & Oud-Vossemeer & 1975 & Waterlandkerkje & 561 \\
\hline Goes & 5825 & Oudelande & 750 & Wemeldinge & 1456 \\
\hline Graauw en Langendam & 1599 & Ouwerkerk & 848 & Westdorpe & 1177 \\
\hline Grijpskerke & 1042 & Overslag & 271 & Westkapelle & 3055 \\
\hline Groede & 2621 & Ovezande & 873 & Wissenkerke & 3850 \\
\hline Haamstede & 1069 & Philippine & 336 & Wolphaartsdijk & 2366 \\
\hline Heinkenszand & 1750 & Poortvliet & 1927 & Yerseke & 1326 \\
\hline Hoedekenskerke & 1015 & Renesse & 662 & Zaamslag & 3766 \\
\hline Hoek & 2087 & Retranchement & 705 & Zierikzee & 5823 \\
\hline Hontenisse & 5212 & Rilland-Bath & 851 & Zonnemaire & 1118 \\
\hline Hoofdplaat & 1374 & Ritthem & 766 & Zoutelande & 856 \\
\hline Hulst & 1974 & 's-Gravenpolder & 823 & Zuiddorpe & 857 \\
\hline IJzendijke & 2109 & 's-Heer Abtskerke & 659 & Zuidzande & 1051 \\
\hline Kapelle & 2681 & 's-Heer Arendskerke & 2352 & & \\
\hline
\end{tabular}


Figure A1: Relative population growth in the Netherlands by province

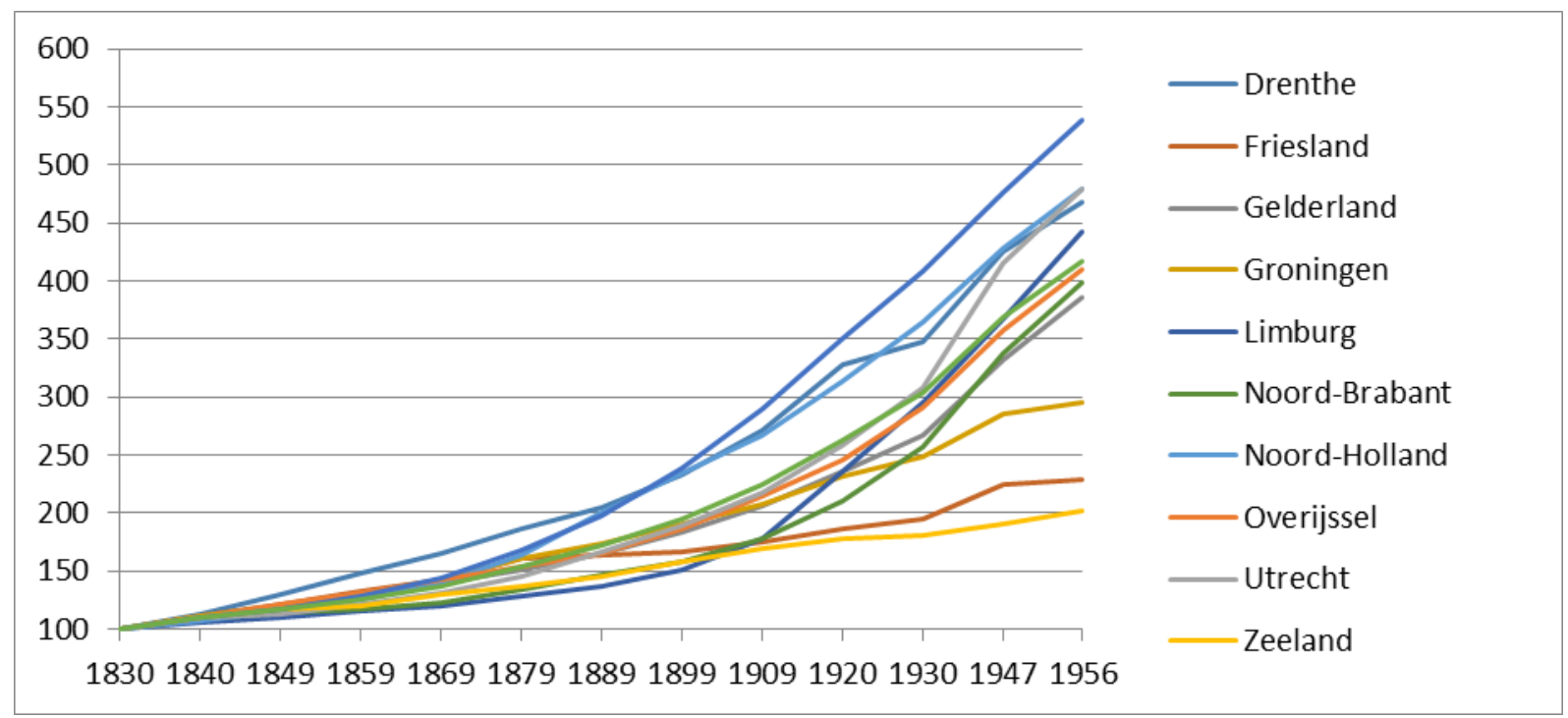

Source: $1830-1956$ census

Figure A2: Roman Catholicism (red), liberal Protestantism (light yellow) and orthodox Protestantism (dark yellow) in Zeeland

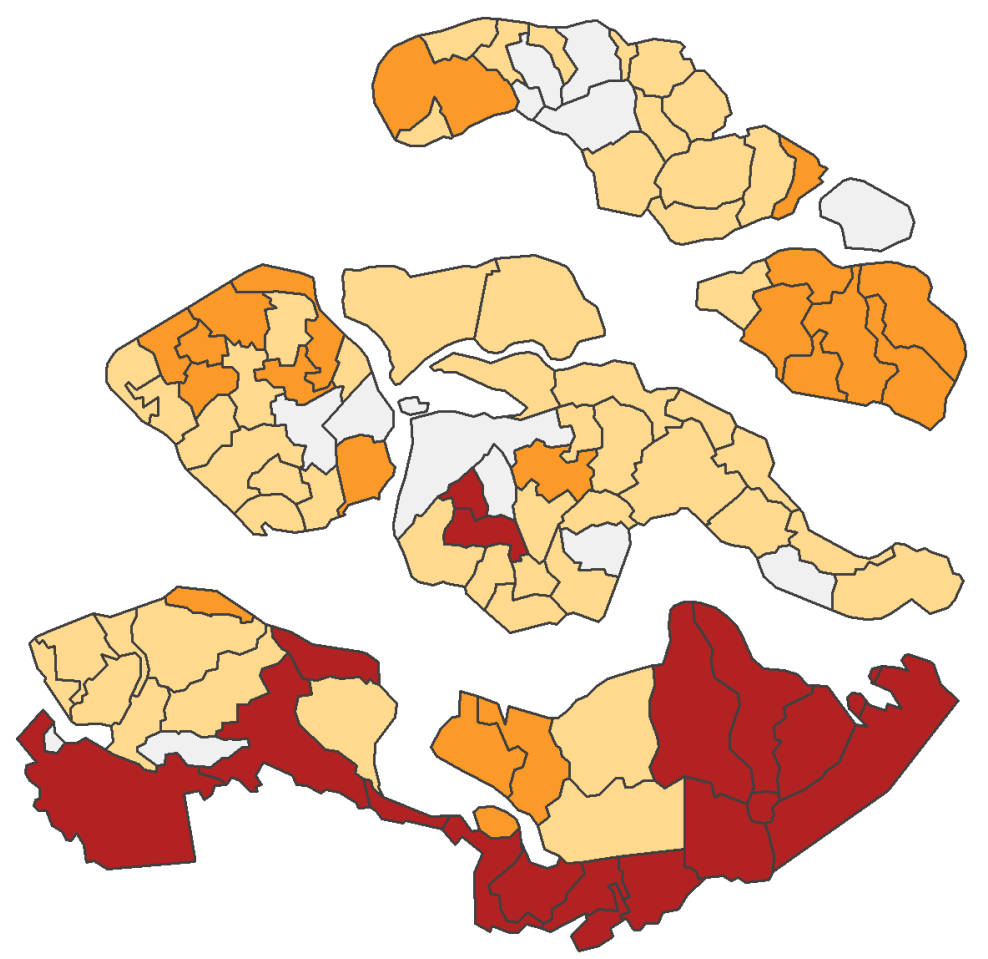


Figure A3: Sandy clay (light yellow) and clay (dark yellow) in Zeeland

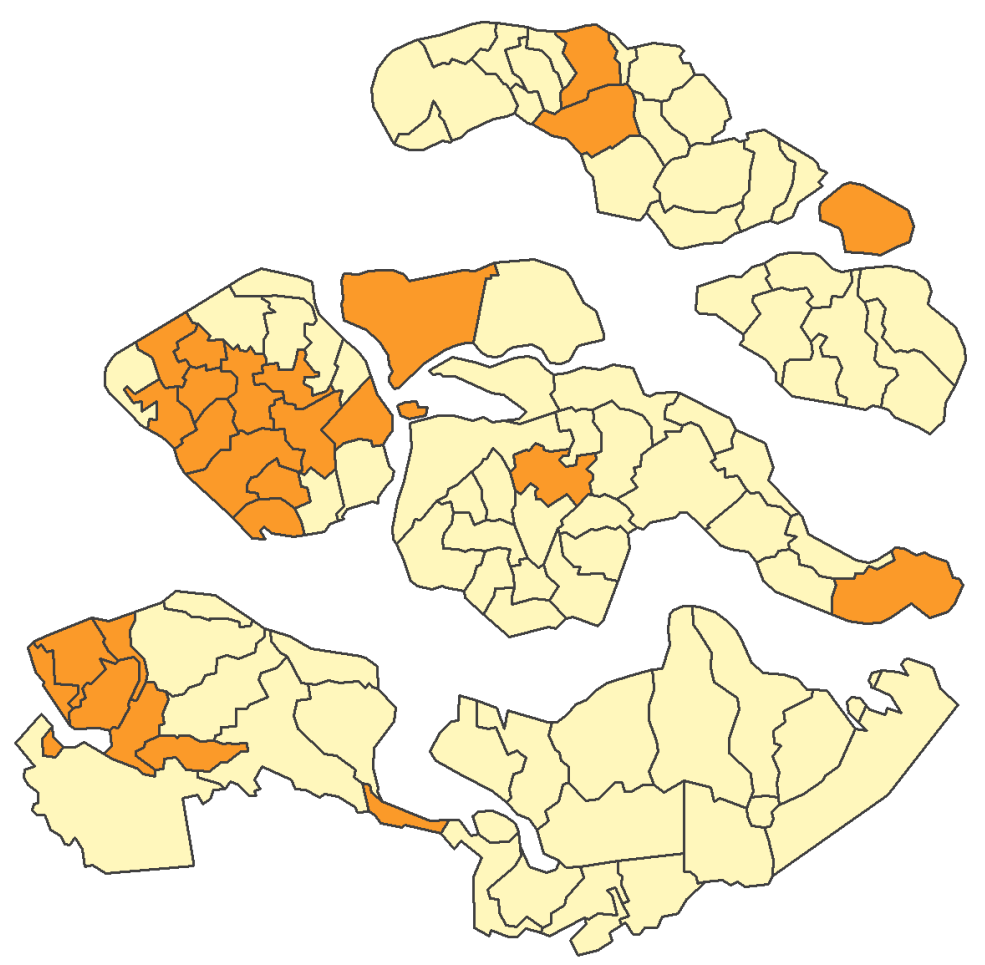

Figure A4: Population density of $<1000,1000-2500$, and $>4,000$ per square hectare in Zeeland

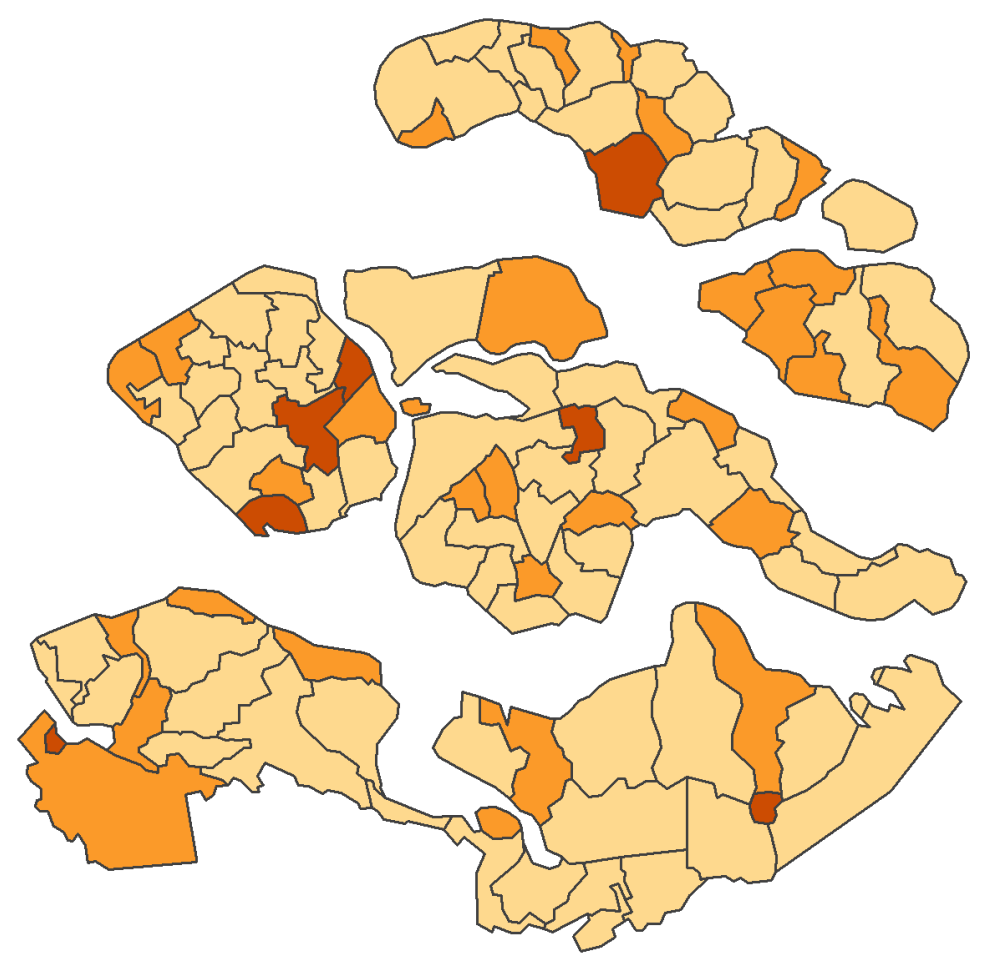


Figure A5: Number of inhabitants in Zeeland

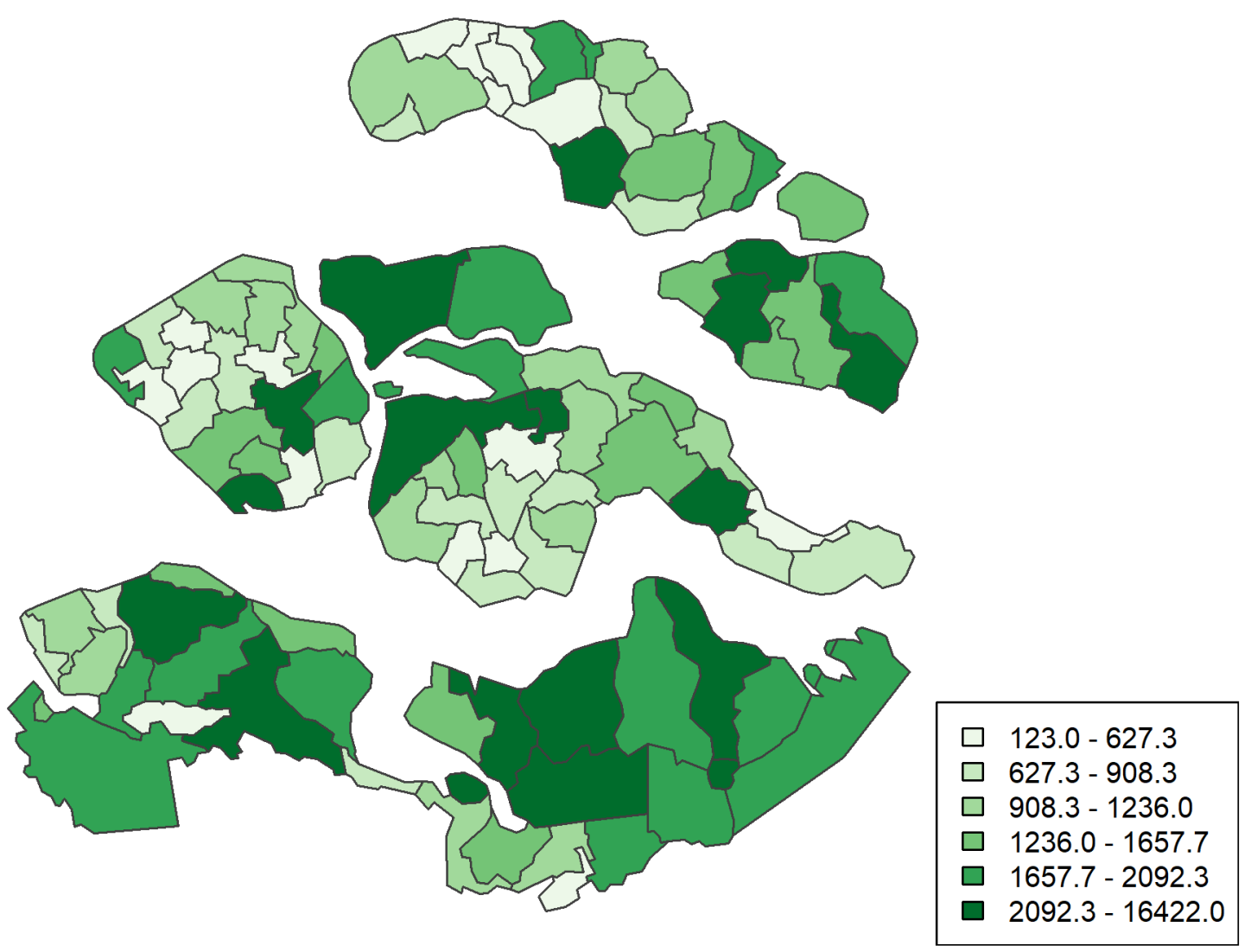

Figure A6: Net taxable income p.c. in Zeeland

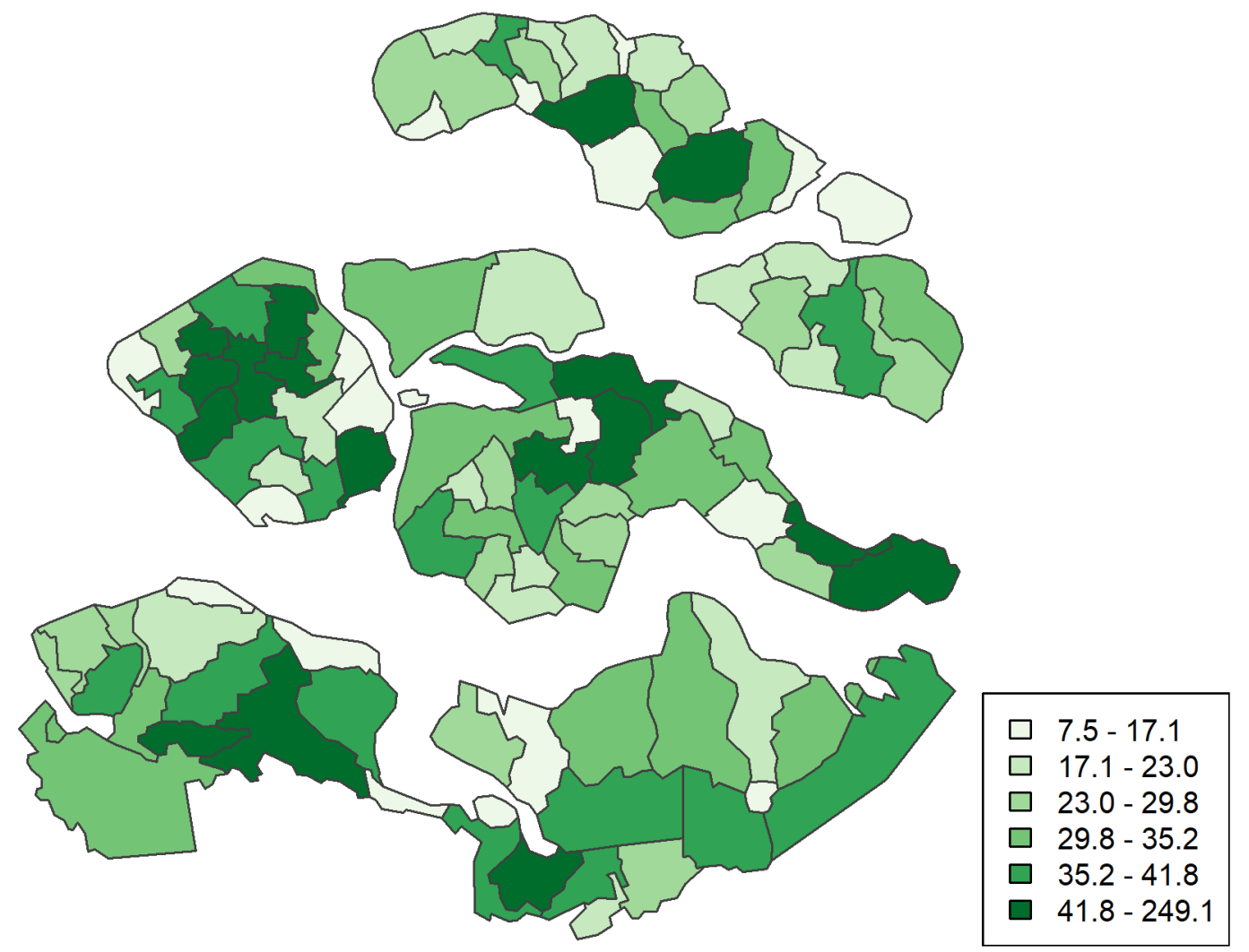


Figure A7: share of the labor force in agriculture

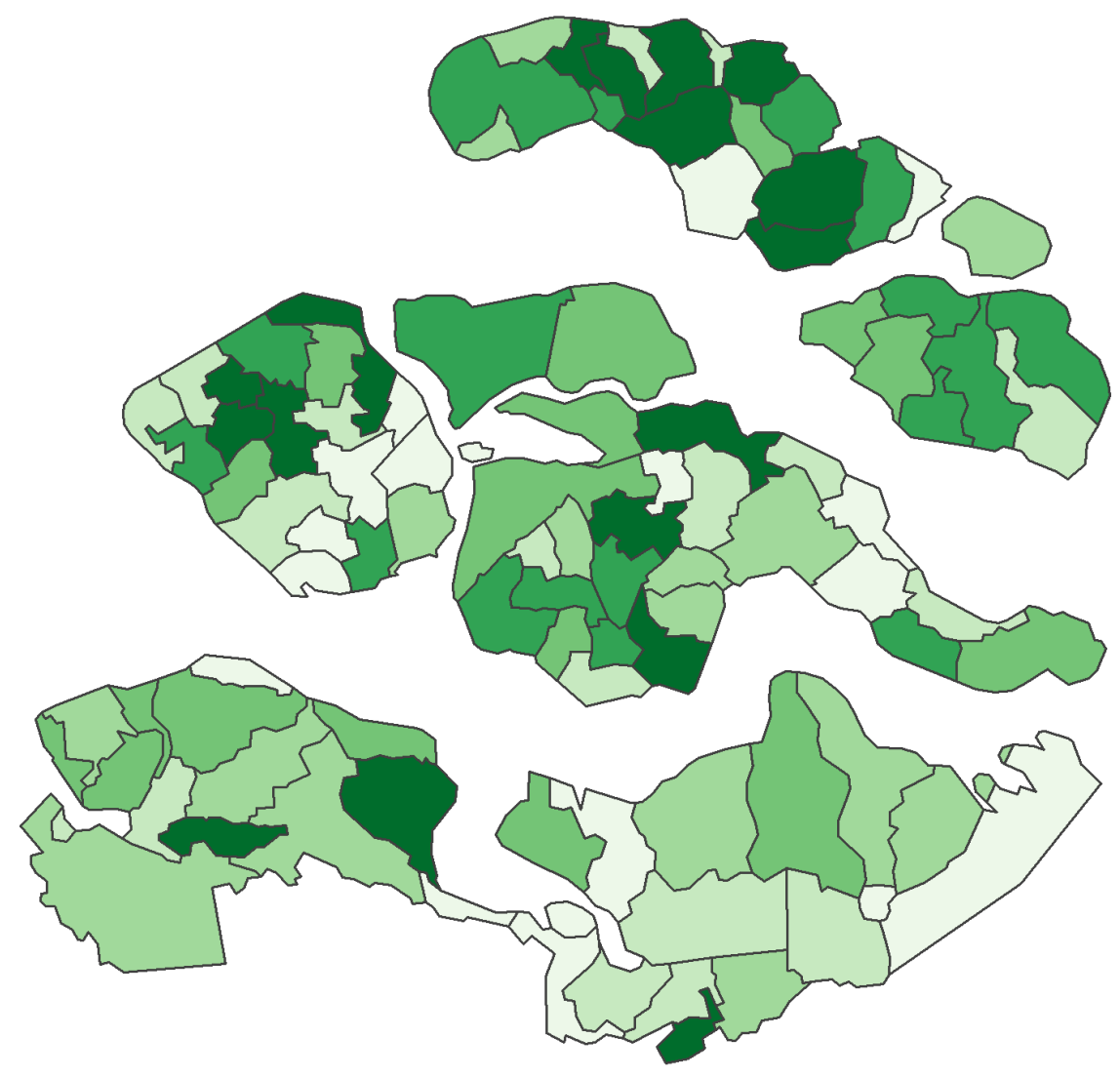

$\square 1.0-37.7$

$37.7-56.6$

$\square \quad 56.6-65.0$

$\square \quad 65.0-68.6$

$\square \quad 68.6-74.4$

$\square 74.4-88.1$

Figure A8: share of the labor force in trade

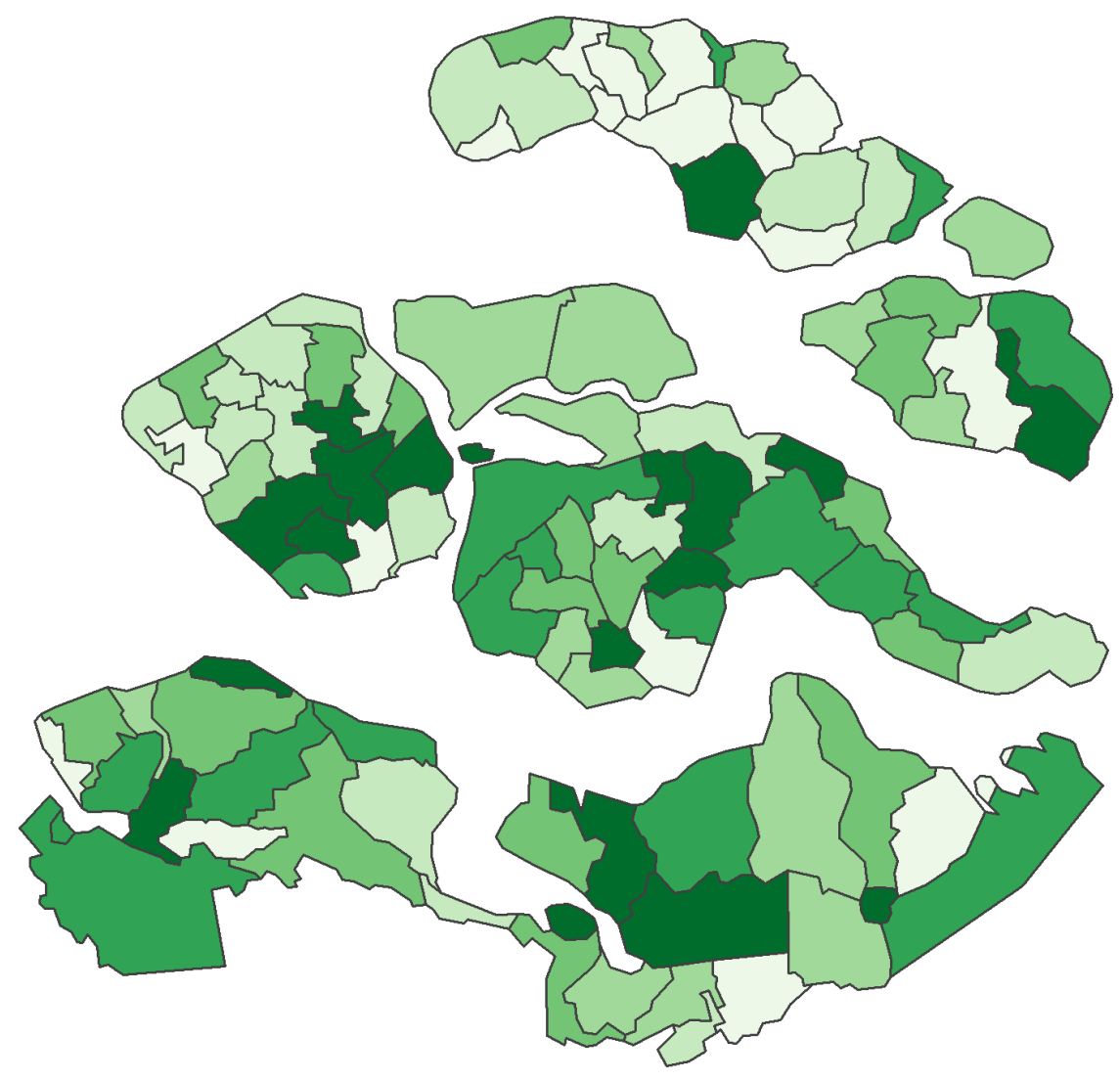

$\square 0.5-2.8$

$\square \quad 2.8-4.1$

$\square \quad 4.1-5.0$

$\square \quad 5.0-6.3$

$\square 6.3-8.7$

$8.7-24.5$ 
Figure A9: Net migration rate

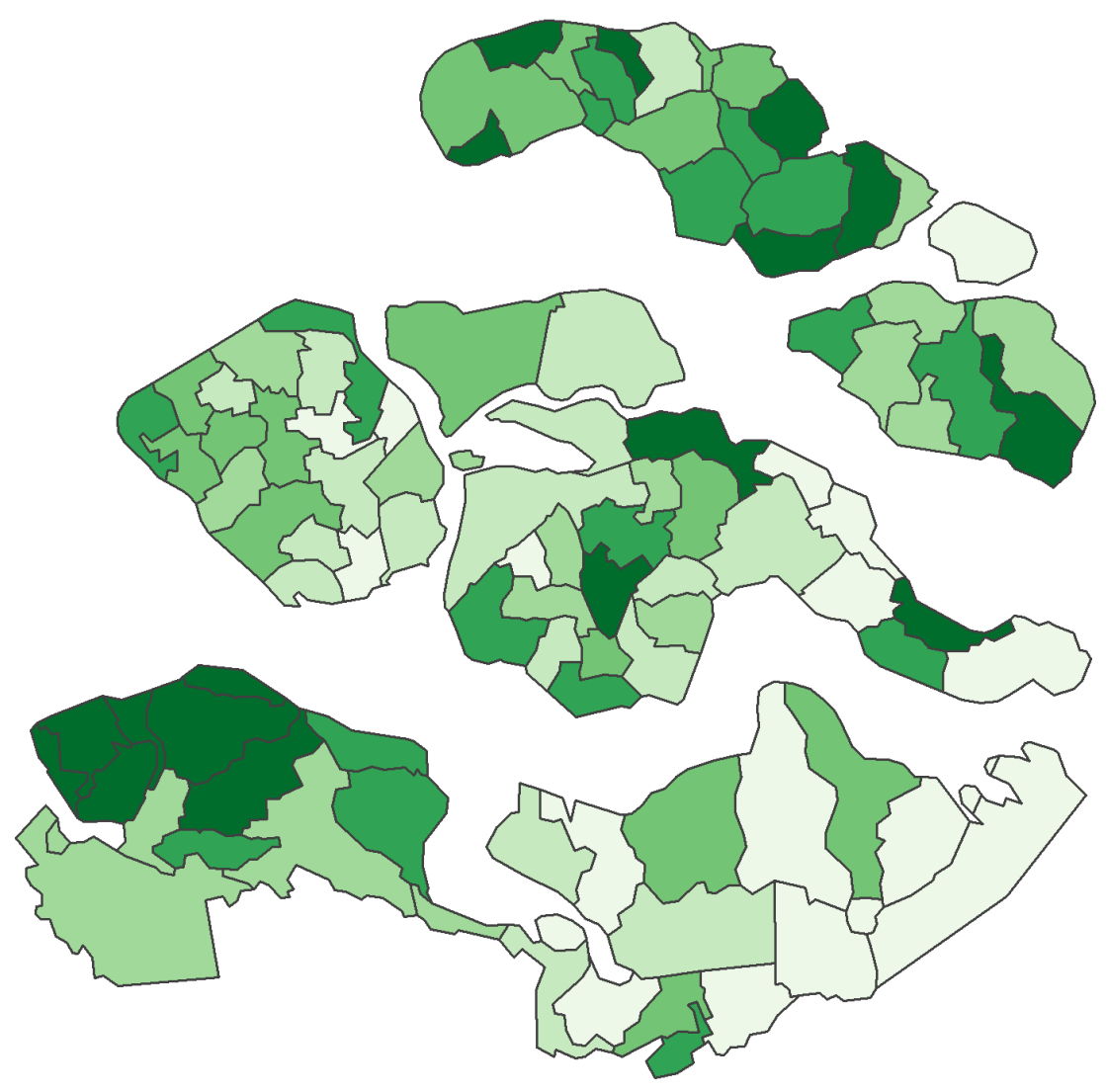

$\square \quad-4.9--1.1$

$\square-1.1--0.8$

$\square \quad-0.8--0.6$

$\square \quad-0.6--0.4$

$\square \quad-0.4--0.2$

$\square \quad-0.2-1.8$

Figure A10: Emigration rate

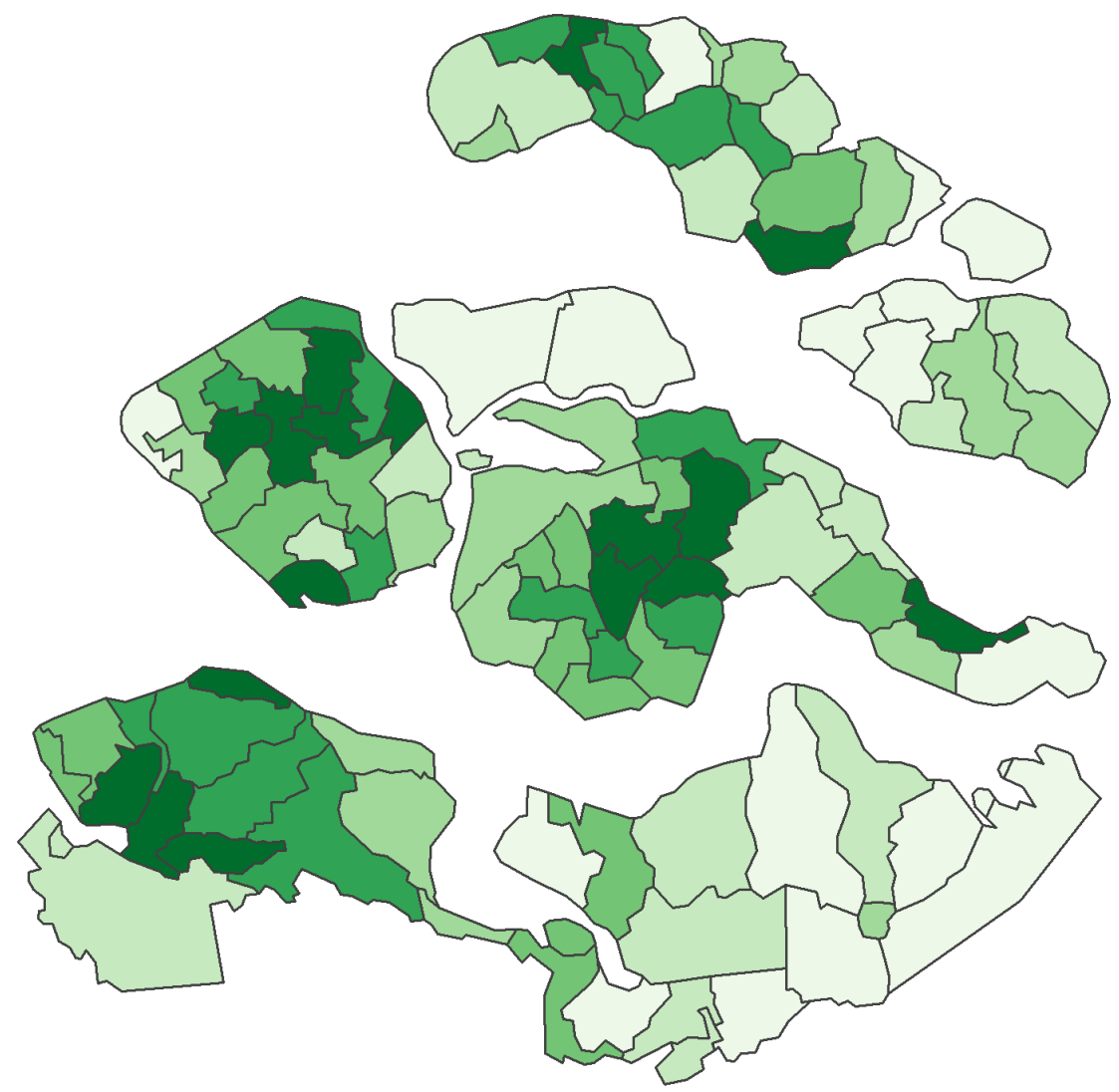

$\square \quad 2.0-3.7$

$\square \quad 3.7-4.6$

$\square \quad 4.6-5.4$

$\square \quad 5.4-6.6$

$\square \quad 6.6-7.4$

$\square 7.4-39.0$ 
Figure A11: Immigration rate

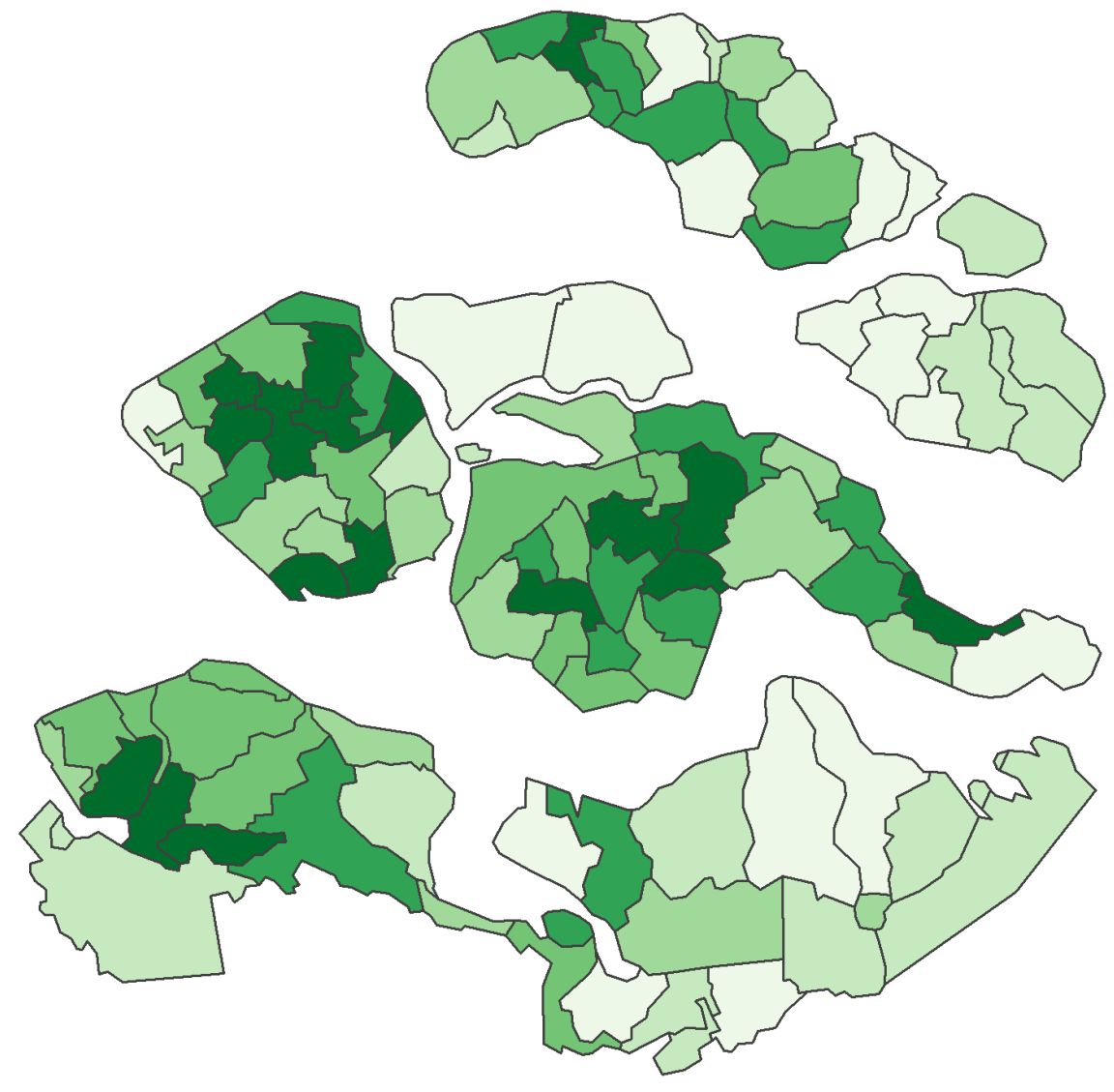

ㅁ $1.7-3.2$

$\square \quad 3.2-3.9$

$\square \quad 3.9-5.0$

$\square \quad 5.0-5.8$

ㅁ $5.8-6.4$

ㅁ $6.4-34.1$ 